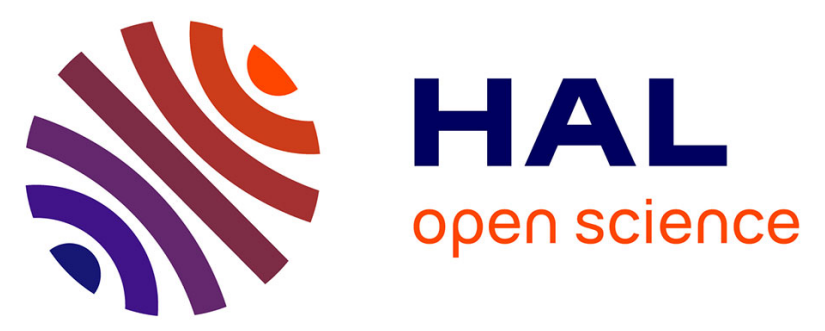

\title{
Neurotensin receptor 2 is induced in astrocytes and brain endothelial cells in relation to neuroinflammation following pilocarpine-induced seizures in rats
}

Grigorios Kyriatzis, Anne Bernard, Angélique Bôle, Guillaume Pflieger, Petros Chalas, Maxime Masse, Pascaline Lécorché, Guillaume Jacquot, Lotfi Ferhat, Michel Khrestchatisky

\section{To cite this version:}

Grigorios Kyriatzis, Anne Bernard, Angélique Bôle, Guillaume Pflieger, Petros Chalas, et al.. Neurotensin receptor 2 is induced in astrocytes and brain endothelial cells in relation to neuroinflammation following pilocarpine-induced seizures in rats. Glia, 2021, 69 (11), pp.2618 - 2643. 10.1002/glia.24062 . hal-03452666

\section{HAL Id: hal-03452666 https://hal.science/hal-03452666}

Submitted on 9 Feb 2022

HAL is a multi-disciplinary open access archive for the deposit and dissemination of scientific research documents, whether they are published or not. The documents may come from teaching and research institutions in France or abroad, or from public or private research centers.
L'archive ouverte pluridisciplinaire HAL, est destinée au dépôt et à la diffusion de documents scientifiques de niveau recherche, publiés ou non, émanant des établissements d'enseignement et de recherche français ou étrangers, des laboratoires publics ou privés. 


\title{
Neurotensin receptor 2 is induced in astrocytes and brain endothelial cells in relation to neuroinflammation following pilocarpine-induced seizures in rats
}

\author{
Grigorios Kyriatzis $^{1}$ | Anne Bernard ${ }^{1}$ | Angélique Bôle ${ }^{1}$ | Guillaume Pflieger ${ }^{1}$ | \\ Petros Chalas $^{1}$ | Maxime Masse ${ }^{2}$ | Pascaline Lécorché ${ }^{2}$ | Guillaume Jacquot ${ }^{2}$ | \\ Lotfi Ferhat $^{1}{ }^{\circledR}$ | Michel Khrestchatisky ${ }^{1}$ (
}

${ }^{1}$ Aix-Marseille University, CNRS, INP, Institute of NeuroPhysiopathology, Marseille Cedex, France

${ }^{2}$ VECT-HORUS, Faculté de Médecine, Marseille Cedex, France

\section{Correspondence}

Lotfi Ferhat and Michel Khrestchatisky, Aix-Marseille University, CNRS, INP, Institute of Neurophysiopathology, Marseille, France. Email: lotfi.ferhat@univ-amu.fr (F. L.);

Email: michel.khrestchatisky@univ-amu.fr (K. M.)

Funding information

AMIDEX ICN PhD Program funded by the French Government «Investissements d'Avenir» program, Grant/Award Number: ANR-11-IDEX-0001-02; European Union Horizon 2020 research and innovation Marie Sklodowska-Curie grant, Grant/Award Number: 642881

\begin{abstract}
Neurotensin (NT) acts as a primary neurotransmitter and neuromodulator in the CNS and has been involved in a number of CNS pathologies including epilepsy. NT mediates its central and peripheral effects by interacting with the NTSR1, NTSR2, and Sort1/NTSR3 receptor subtypes. To date, little is known about the precise expression of the NT receptors in brain neural cells and their regulation in pathology. In the present work, we studied the cellular distribution of the NTSR2 protein in the rat hippocampus and questioned whether its expression was modulated in conditions of neuroinflammation using a model of temporal lobe epilepsy induced by pilocarpine. This model is characterized by a rapid and intense inflammatory reaction with reactive gliosis in the hippocampus. We show that NTSR2 protein is expressed in hippocampal astrocytes and its expression increases together with astrocyte reactivity following induction of status epilepticus. NTSR2 immunoreactivity is also increased in astrocytes proximal to blood vessels and their end-feet, and in endothelial cells. Proinflammatory factors such as IL1 $\beta$ and LPS induced NTSR2 mRNA and protein in cultured astroglial cells. Antagonizing NTSR2 with SR142948A decreased NTSR2 expression as well as astroglial reactivity. Together, our results suggest that NTSR2 is implicated in astroglial and gliovascular inflammation and that targeting the NTSR2 receptor may open new avenues in the regulation of neuroinflammation in CNS diseases.
\end{abstract}

KEYWORDS

blood-brain barrier, epilepsy, IL1 $\beta$, kainate, microglia, NTSR2, proinflammatory factors

\section{INTRODUCTION}

Neurotensin (NT) is a tridecapeptide highly conserved between species, found in the mammalian central nervous system (CNS) and periphery. In the CNS, NT is found at high concentrations in the limbic

Lotfi Ferhat and Michel Khrestchatisky are equal last authors. system, including the hippocampus (Sarret et al., 2003). It is a primary neurotransmitter/neuromodulator that mediates analgesia and is implicated in thermoregulation, memory consolidation, and in learning processes (Dobner, 2005; Friry et al., 2002; Nemeroff et al., 1992; Vincent, 1995). NT has been involved in a number of psychiatric pathologies including schizophrenia (Sharma et al., 1997), in Parkinson's disease (Hernandez-Chan et al., 2015), glioma (Ouyang 
et al., 2015), pain (Williams et al., 1995), cerebral ischemia (Torup et al., 2003), and epilepsy (Lee et al., 2009; St-Gelais et al., 2006). In vitro it has been implicated in protection against apoptosis in different cell types (reviewed in Devader et al., 2013).

NT mediates its central and peripheral effects by interacting with three receptor subtypes, namely NTSR1, NTSR2, and gp95/Sortilin (Sort1) or NTSR3. NTSR1 and NTSR2 are G protein-coupled receptors with seven transmembrane domains (Vincent, 1995). Sort1/NTSR3 is a type I receptor with a single transmembrane domain and is not coupled to a G protein (Mazella, 2001). To date, not much is known about the potential role of NT in modulating neuroprotection and neuroinflammation and which receptors are involved, in which brain structures and cell types. NTSR1 and NTSR2 show high and low affinity for NT, respectively (Chalon et al., 1996; Tanaka et al., 1990), and these two receptors are found in different cell types of the nervous system at different developmental stages. NTSR1 is expressed prenatally in many rat brain structures, its expression peaks shortly after birth and is decreased in adulthood (Palacios et al., 1988). On the other hand, NTSR2 expression is essentially postnatal and increases progressively with age (Lépée-Lorgeoux et al., 1999; Sarret et al., 1998), raising interest on the role of this receptor in brain physiopathology.

NTSR2 is a $45 \mathrm{kDa}$ protein in humans and rodents, endowed with lower affinity for NT compared with the other NT receptors (NTSRs) $\left(K_{\mathrm{d}}=3-10 \mathrm{nmol} / \mathrm{L}\right.$ compared with $0.1-0.3 \mathrm{nmol} / \mathrm{L}$ for NTSR1 and Sort1/NTSR3, respectively) (Sarret \& Beaudet, 2002; St-Gelais et al., 2006). Besides its expression in pancreatic $\beta$ cells (BéraudDufour et al., 2009) and human B lymphocytes (Saada et al., 2012), NTSR2 is essentially expressed in the CNS, including the hippocampus, cerebral cortex, cerebellum, olfactory bulb, substantia nigra, and ventral tegmental area (Lépée-Lorgeoux et al., 1999; Sarret et al., 2003; Walker et al., 1998). Rat NTSR2 mRNA expression was shown in astrocytes in vivo (Walker et al., 1998; Yamauchi et al., 2007), and NTSR2 protein immunofluorescence was reported in astrocytes in the ventral tegmental area in mice (Woodworth et al., 2018). In contrast, another study reported no NTSR2 immunostaining in astrocytes in adult rat brain (Sarret et al., 2003). Thus, astrocytic expression of NTSR2 remains controversial, and up to now, the data available is limited.

Previous studies have associated NT and seizures. In the kainate (KA) model of temporal lobe epilepsy (TLE), NT-like immunoreactivity in the rat hippocampus was reduced after onset of seizures, suggesting NT release (Sperk et al., 1986). Intracerebroventricular (i.c.v) or intraperitoneal (i.p.) administration of NT or its analogues showed anti-convulsant effects in a corneal stimulation mouse model of pharmaco-resistant epilepsy (Green et al., 2010; Lee et al., 2009). However, the mechanisms by which neurotensin receptors (NTSRs) mediate anti-convulsive effects remain unknown. At the same time, NT can promote proinflammatory responses of immune cells with the release of interleukins and chemotactic molecules (Koon et al., 2009; Zhao et al., 2003). Also, NTSR2 mRNA expression can be increased by proinflammatory stimulation in purified astrocytes (Pang et al., 2001).

In the present work, we assessed the expression of NTSR2 in the hippocampus, both in physiological and pathological conditions. In particular, we questioned whether expression of the NTSR2 receptor was modulated in conditions of neuroinflammation using a pathophysiological model of TLE induced by pilocarpine in rats. In this model, animals undergo a rapid and intense neuroinflammatory reaction with a pattern of reactive gliosis in the hippocampus involving the activation of microglia and astrocytes (Clifford et al., 1987; Garzillo \& Mello, 2002).

Our study shows unambiguous expression of NTSR2 protein in hippocampal astrocytes both in vivo and in vitro. In pilocarpinetreated rats, NTSR2 expression was increased rapidly when neuroinflammation peaks, and decreased at the chronic phase (3 months), when astrocyte reactivity subsides (Choi \& Koh, 2008; Garzillo \& Mello, 2002). We also observed increased NTSR2 expression in blood vessels, specifically in astrocytic end-feet and endothelial cells during inflammation. We showed that NTSR2 mRNA and protein expression were induced in inflamed cultured glial cells and that antagonizing NTSR2 with the SR142948A antagonist downregulated NTSR2 protein expression and glial reactivity in vitro. In all, our work demonstrates the involvement of the neurotensinergic system in hippocampal astrocytes and in the glio-vascular unit during neuroinflammation and suggests that targeting the NTSR2 receptor could modulate neuroinflammation.

\section{2 | MATERIALS AND METHODS}

\subsection{Experimental animals}

All experimental procedures involving rats and mice were approved by National and European regulations (EU directive No. 2010/63) and were in agreement with the authorization for animal experimentation granted to the laboratory by the Prefecture des Bouches du Rhône (permit number: D 13055 08) and to the project (No 00757.02) by the French Ministry of Research and Local Ethics Committee. Animals were treated according to Appendix A of the European Convention for the Protection of Vertebrate Animals used for Experimental and other Scientific Purposes, ETS No. 123. Animals were maintained in the animal facility with $12 \mathrm{~h}$ light-dark cycles, had access to food and water ad libitum and all efforts were made to minimize animal suffering and to reduce the number of animals used.

\section{2 | Rat pilocarpine temporal lobe epilepsy model}

Adult male Wistar rats weighing 200-290 g (Charles River, France) were first injected i.p. with a low dose of the cholinergic antagonist scopolamine methyl nitrate ( $2 \mathrm{mg} / \mathrm{kg}$; Sigma, Saint Louis, Missouri), in order to minimize the peripheral effects of pilocarpine hydrochloride (320 mg/kg; Sigma), a muscarinic cholinergic agonist diluted in $0.9 \%$ $\mathrm{NaCl}$ and administered i.p. $30 \mathrm{~min}$ after scopolamine. Control rats received an injection of $0.9 \% \mathrm{NaCl}$. The injection protocols were similar to those previously described, including by us, for the generation of TLE (Cragnolini et al., 2009; Mello et al., 1993; Obenaus et al., 1993; Sbai et al., 2012; Sbai et al., 2021; Soussi et al., 2015). 
Only animals that developed status epilepticus (SE) after pilocarpine injection were included in the study. To reduce animal mortality, SE was stopped after $1 \mathrm{~h}$ by two injections of Diazepam (Valium) with a 15-min interval (10 mg/kg i.p., Roche, France). Pilocarpine-treated animals were observed periodically for general behavior and occurrence of spontaneous seizures. They were studied at several post-injection intervals: during the latent period, when animals displayed an apparently normal behavior ( 3 days, 1 and 2 weeks, $n \geq 6$ at each time point), and during the chronic stage, when the animals developed spontaneous recurrent limbic seizures (12 weeks; $n \geq 6$ ). During the following days after induction of SE, animals were nurtured and assisted to drink water. For the weakest ones, a double dose of $\mathrm{NaCl}$ $0.9 \%$ and glucose $(10 \mathrm{mg} / \mathrm{kg}$, i.p.) was provided twice per day until animals regained their weight or reached the endpoint. Animals were housed two per cage in enriched environment to minimize stress prior to $\mathrm{SE}$ and one per cage to avoid aggressive behavior post-SE.

\section{3 | Mouse kainate temporal lobe epilepsy model}

As a second model of TLE, young adult male FVB/N mice (Janvier Laboratories, France), 25-30 g, 9-10 weeks old, were injected subcutaneously with a single dose of KA, $40-45 \mathrm{mg} / \mathrm{kg}$; Abcam, France) to generate mice with spontaneous recurrent seizures as a hallmark of SE as previously described (Schauwecker \& Steward, 1997). All animals were housed six per cage. KA-injected mice were individually housed and received a $0.5 \mathrm{ml}$ i.p. dose of glucose and also had free access to Doliprane (Paracetamol, Sanofi, Gentilly, France) at $2.4 \%$ in agarose gel in order to reduce pain. Mice were observed during $9 \mathrm{~h}$ for onset and extent of seizure activity and only mice developing typical SE were included in the study. Body weight was monitored daily.

\section{4 | Tissue preparation}

Rats were deeply anesthetized with pentobarbital sodium injection (Nembutal, $120 \mathrm{mg} / \mathrm{kg}$ i.p., Ceva, France) and perfused through the heart with a fixative paraformaldehyde-based solution (Antigenfix, Diapath, Italy). The brains were then removed from the skull $30 \mathrm{~min}$ later, and were post-fixed in the same fixative solution for $24 \mathrm{~h}$ at $4^{\circ} \mathrm{C}$. Finally, brains were rinsed three times in phosphate buffer (0.12 M; PB, pH 7.2-7.4) and cryoprotected in $30 \%$ sucrose solution in PB $0.12 \mathrm{M}$ until fully dehydrated. Brains were first frozen in isopentane solution (Sigma) at $-80^{\circ} \mathrm{C}$ and then fixed in O.C.T. Tissue Tek (Sakura Finetek, Torrance, California) and sectioned coronally at $40 \mu \mathrm{m}$ with a cryostat. The sections were collected sequentially in wells of culture plates containing an ethylene glycol-based cryoprotective solution and stored at $-20^{\circ} \mathrm{C}$ until processing. Selected sections from each rat covering the dorsal hippocampus (from bregma -3.30 to $-4.80 \mathrm{~mm}$ according to the Rat Brain Atlas [Paxinos \& Watson, 1998]), were used for immunohistochemical staining. Free-floating sections from control (CTL) and pilocarpine-treated rats (PILO) were always processed in parallel.
Mice were deeply anesthetized with chloral hydrate $(700 \mathrm{mg} / \mathrm{kg}$; ProLabo, France) and transcardially perfused with Antigenfix solution. The brains were extracted and post-fixed for $1 \mathrm{~h}$ at room temperature $(\mathrm{RT})$ and rinsed in PB $0.12 \mathrm{M}$. Forty $\mu \mathrm{m}$ coronal sections were generated using a vibratome, immersed in a cryoprotective solution, and stored at $-20^{\circ} \mathrm{C}$ until use for immunofluorescence. Selected sections from the dorsal hippocampus of each mouse (bregma -1.55 to -2.35 $\mathrm{mm}$ according to the Mouse Brain Atlas [Paxinos \& Franklin, 2019]), were processed for immunohistochemistry. Mice were sacrificed at 7 days post-SE (KA 7D).

\section{5 | Immunohistochemistry}

For double labeling with primary antibodies originating from the same host species, in our case rabbit (NTSR2 and GFAP/Iba1; IL1 $\beta / G F A P)$, a protocol from Jackson ImmunoResearch was used and optimized for our purpose. Free-floating sections from the dorsal hippocampus of CTL and PILO rats or CTL and KA mice were processed in parallel. Information on primary antibodies used in this study are summarized in Table 1. Free-floating sections were permeabilized in a solution containing $3 \%$ bovine serum albumin (BSA) and $0.3 \%$ Triton $\mathrm{X}-100$ in PB $0.12 \mathrm{M}$ for $1 \mathrm{~h}$ at RT. Following permeabilization, sections were first incubated overnight at $4{ }^{\circ} \mathrm{C}$ with rabbit anti-NTSR2 diluted in a blocking solution containing 3\% BSA diluted in PB $0.12 \mathrm{M}$. The next day, slices were washed three times in PB $0.12 \mathrm{M}$ under agitation and incubated with secondary antibody, goat anti-rabbit biotin (Life Technologies, France) diluted in the blocking solution (1:200) for $2 \mathrm{~h}$, and then revealed with streptavidin IgG conjugated with AlexaFluor 488 (Jackson ImmunoResearch, West Grove, Pennsylvania) diluted in blocking solution (1:800) for $2 \mathrm{~h}$, always in dark. Next, slices were washed three times in PB $0.12 \mathrm{M}$ and incubated with normal rabbit serum (Jackson ImmunoResearch) diluted (1:20) in PB $0.12 \mathrm{M}$ for $2 \mathrm{~h}$ at RT, to saturate open binding sites on the first secondary antibody with IgG. Following three washes in PB $0.12 \mathrm{M}$, slices were incubated with unconjugated Fab goat anti-rabbit IgG $(\mathrm{H}+\mathrm{L})(20 \mu \mathrm{g} / \mathrm{ml})$ (Jackson ImmunoResearch) diluted in PB $0.12 \mathrm{M}$ for $2 \mathrm{~h}$ at RT, to cloak the rabbit IgG and hamper binding of the second secondary antibody. Slices were incubated overnight at $4^{\circ} \mathrm{C}$ under agitation with rabbit anti-GFAP or anti-lba1. The last day, slices were washed three times in PB $0.12 \mathrm{M}$ and incubated with a goat anti-rabbit IgG $(\mathrm{H}+\mathrm{L})$ highly cross-adsorbed AlexaFluor A594 (Life Technologies) diluted in blocking solution (1:1000) for $2 \mathrm{~h}$. Nuclei were counterstained with $5 \mu \mathrm{g} / \mathrm{ml}$ 4',6-diamidino-2-phenylindole (DAPI, Sigma) for $0.5 \mathrm{~h}$ at RT. After three washes in PB $0.12 \mathrm{M}$, floating sections were mounted on Superfrost Plus glass slides using Fluoromount-G Mounting medium (Electron Microscopy Sciences, Hatfield, Pennsylvania) and stored at $-20^{\circ} \mathrm{C}$ until imaging and analysis.

This protocol was also used for triple immunofluorescence labeling including two antibodies from the same host species (rabbit PDGFR $\beta$ /rabbit NTSR2/mouse CD31 for rat tissue or rat CD31 for mouse tissue), by incubating the slices the third day with mouse or rat anti-CD31 overnight. Labeling was revealed by streptavidin IgG 


\begin{tabular}{|c|c|c|c|c|}
\hline \multirow[b]{2}{*}{ Antibodies } & \multirow[b]{2}{*}{ Species } & \multirow[b]{2}{*}{ Sources and references } & \multicolumn{2}{|c|}{ Dilution } \\
\hline & & & IF & WB \\
\hline NTSR2 & Rabbit & Novus Biologicals, NBP1-00959 & $1: 100$ & $1: 200$ \\
\hline GFAP & Rabbit & Dako, Z0334 & $1: 500$ & \\
\hline Iba1 & Rabbit & Wako, 019-19741 & $1: 500$ & \\
\hline PDGFR- $\beta$ & Rabbit & Abcam, ab32570 & 1:100 & \\
\hline Collagen IV & Goat & Southern Biotech, 1340-01 & $1: 250$ & \\
\hline CD31 & Mouse & Abcam, ab64543 & $1: 100$ & \\
\hline CD31 & Rat & Abcam, ab56299 & 1:100 & \\
\hline GAPDH & Mouse & Millipore, Mab374 & & $1: 5000$ \\
\hline NTSR3 & Mouse & Santa Cruz, E-9, sc-376576 & & $1: 200$ \\
\hline IL-1 $\beta$ & Rabbit & Bioss, bs-6319R & $1: 300$ & \\
\hline
\end{tabular}

TABLE 1 Primary antibodies used for immunofluorescence (IF) and Western blot (WB) analysis conjugated with AlexaFluor A488 (Jackson ImmunoResearch) for PDGFR $\beta$, goat anti-rabbit IgG $(\mathrm{H}+\mathrm{L})$ highly cross-adsorbed AlexaFluor A647 (1:1000) (Life Technologies) for NTSR2, and goat anti-mouse IgG1 $(\mathrm{H}+\mathrm{L})$ cross-adsorbed AlexaFluor A594 (1:800) or goat anti-rat IgG $(\mathrm{H}+\mathrm{L})$ cross-adsorbed AlexaFluor A594 (1:800) (Life Technologies) for CD31.

Finally, for double or triple immunofluorescence labeling for antibodies from different host species (rabbit IL1 $\beta /$ mouse MAP2; goat ColIV/rabbit NTSR2/mouse CD31 for rat tissue or rat CD31 for mouse tissue), slices were incubated sequentially overnight with each one of the primary antibodies, and on the fourth day they were incubated with the appropriate secondary antibodies: donkey anti-goat $\operatorname{lgG}(\mathrm{H}+\mathrm{L})$ highly cross-adsorbed AlexaFluor A488 for CollV, donkey anti-rabbit IgG $(\mathrm{H}+\mathrm{L})$ highly cross-adsorbed AlexaFluor $\mathrm{A} 647$ for NTSR2, and donkey anti-mouse $\operatorname{lgG}(\mathrm{H}+\mathrm{L})$ highly cross-adsorbed AlexaFluor A594 or donkey anti-rat IgG $(\mathrm{H}+\mathrm{L})$ highly cross-adsorbed AlexaFluor A594 for CD31 (Life Technologies), diluted in blocking solution (1:800). Regarding IL1 $\beta$ revelation, slices were incubated with goat anti-rabbit biotin (Life Technologies) diluted in blocking solution (1:200) for $2 \mathrm{~h}$, and then revealed with streptavidin IgG conjugated with AlexaFluor 488 (Jackson ImmunoResearch) diluted in blocking solution (1:800) for $2 \mathrm{~h}$. Regarding MAP2 revelation, slices were incubated with goat anti-mouse $\operatorname{lgG}(\mathrm{H}+\mathrm{L})$ highly cross-adsorbed AlexaFluor A594 (Life Technologies) diluted in blocking solution (1:800) for $2 \mathrm{~h}$.

The specificity of the double immunohistochemical labeling for antibodies originating from the same host such as NTSR2, GFAP, Iba1, or IL1 $\beta$ (or triple labeling including two antibodies from same host) was tested by incubating some sections from CTL and PILO/KA animals with two primary antibodies with different targets; GFAP (rabbit, for astrocytes) and Iba1 (rabbit, for microglia). The two antibodies gave a clearly distinctive specific pattern and did not overlap. To assess blocking efficiency, the second primary antibody was omitted, but not the corresponding secondary antibody. In all cases, the second secondary antibody did not detect the first primary antibody. Additional controls included incubation of some sections in a mixture of one primary antibody and biotinylated rabbit normal IgG, or rabbit normal IgG. The pattern of immunolabeling of these sections was the same as for sections processed for single labeling.

\subsection{Primary glial cell cultures}

Glial cells (astrocytes, microglia) were prepared from embryonic day 18 (E18) or newborn (P0) rat cortices as we described previously (Mahler et al., 1997). Briefly, rats were killed by decapitation, brains were removed, and cortices were dissected out and cleared from the meninges. Pieces of cortices were digested in a TrypsinEDTA $\times 1$ solution for $15 \mathrm{~min}$ at $37^{\circ} \mathrm{C}$ and rinsed three times in HBSS $\times 1$ followed by three rinses in Dulbecco's Modified Eagle Medium Glutamax $\times 1$ (DMEM) supplemented with $10 \%(\mathrm{v} / \mathrm{v})$ heatinactivated Fetal Bovine Serum (FBS). Next, cortices were mechanically dissociated by successive pipetting in DMEM supplemented with FBS. Dissociated cells were grown in DMEM supplemented with $10 \%$ FBS and 100 i.u./ml penicillin/streptomycin (all supplements were from Thermo Fisher Scientific, France). The cells were seeded at a density of 200,000 cells/flask in T25 flasks for RTqPCR, 50,000 cells/well in 12-well plates for qualitative images and at 10,000 cells/well in 96 -well plates for pharmacological treatments, and cultured at $37^{\circ} \mathrm{C}, 5 \% \mathrm{CO}_{2}$. The medium was changed twice per week and the cells were assessed experimentally after 14 days in culture.

\subsection{Induction of inflammation and pharmacological treatments in primary glial cultures}

Inflammation in primary glial cultures was induced by the addition of proinflammatory agents such as interleukin 1 beta (IL1 $\beta, 10 \mathrm{ng} / \mathrm{ml}$; PeproTech, France) or lipopolysaccharide (LPS, $1 \mu \mathrm{g} / \mathrm{ml}$; Sigma) for 1,6 , and $24 \mathrm{~h}$, at $37^{\circ} \mathrm{C}$, as we described previously (Gueye et al., 2011). The supernatants were collected and centrifuged, and 
cells were used for RNA extraction and RT-qPCR analyses. Cultures were also incubated with $1 \mu \mathrm{M} N T$ (provided by Vect-Horus, Marseille, France), $1 \mu \mathrm{M}$ Levocabastine (Levo), or $1 \mu \mathrm{M}$ SR142948A (SR) (both from Sigma), for $24 \mathrm{~h}$ in the presence or absence of LPS. After $24 \mathrm{~h}$, medium was removed, and cells were washed in PB and then fixed by a solution of $4 \%$ paraformaldehyde (PFA, Sigma) for $20 \mathrm{~min}$ at RT. For immediate-early gene responses in vitro, primary glial cultures were incubated with the protein synthesis inhibitor cycloheximide (CHX, $10 \mu \mathrm{g} / \mathrm{ml}$, Cell Signaling Technology, Massachusetts) in the presence or absence of LPS for 1, 6, and $24 \mathrm{~h}$ at $37^{\circ} \mathrm{C}$

\section{8 | Immunocytochemistry}

Cell coated coverslips in 12-well or 96-well plates were rinsed three times with PB $0.12 \mathrm{M}$ and permeabilized in a blocking solution containing 3\% BSA and $0.1 \%$ Triton $\mathrm{X}-100$ diluted in $\mathrm{PB} 0.12 \mathrm{M}$ for $30 \mathrm{~min}$ at RT. Cells were incubated overnight with rabbit anti-NTSR2 antibody diluted in 3\% BSA blocking solution inside a humidity chamber at $4^{\circ} \mathrm{C}$. The next day, wells were washed three times in PB $0.12 \mathrm{M}$ at RT and incubated, always in dark, with goat anti-rabbit IgG $(\mathrm{H}+\mathrm{L})$ highly cross-adsorbed AlexaFluor A488 (1:800, Life Technologies) diluted in the blocking solution for $2 \mathrm{~h}$. After three washes in $\mathrm{PB}$ $0.12 \mathrm{M}$, cells were incubated with normal rabbit serum (1:20) for $2 \mathrm{~h}$ and then with Fab goat anti-rabbit IgG $(20 \mu \mathrm{g} / \mathrm{ml})$ for another $2 \mathrm{~h}$ at RT before incubation with rabbit anti-GFAP or rabbit anti-lba1 at $4^{\circ} \mathrm{C}$ overnight. The last day, cells were washed three times in PB $0.12 \mathrm{M}$ and incubated with goat anti-rabbit $\lg \mathrm{G}(\mathrm{H}+\mathrm{L})$ highly cross-adsorbed AlexaFluor A594 (1:1000, Life Technologies) diluted in the blocking solution for $2 \mathrm{~h}$ at RT. Nuclei were counterstained with $5 \mu \mathrm{g} / \mathrm{ml}$ DAPI for $0.5 \mathrm{~h}$ at RT. After three washes in PB $0.12 \mathrm{M}$, coverslips were rapidly rinsed three times in distilled water and let to dry before mounting on Superfrost glass slides using Fluoromount-G Mounting medium and stored at $-20^{\circ} \mathrm{C}$. Labeling specificity was assessed under the same conditions, by incubating some coverslips/wells from control and treated cells in a solution omitting one of the primary antibodies, and, furthermore, the specificity of the double immunolabeling for antibodies originating from the same host was evaluated by incubating some coverslips with two primary antibodies with different targets, GFAP and Iba1. In all cases, no overlap of antibodies was detected.

\section{9 | Monocyte chemoattractant protein $1 /$ chemokine $\mathrm{C}-\mathrm{C}$ motif ligand 2 ELISA assay}

Monocyte chemoattractant protein $1 /$ chemokine C-C motif ligand 2 (MCP1/CCL-2) levels were evaluated using a commercially available ELISA kit (PeproTech) according to the manufacturer's instructions. All samples were analyzed in triplicate. The detection threshold was $16 \mathrm{pg} / \mathrm{ml}$.

\subsection{RNA extraction and RT-qPCR}

Total RNA was prepared from primary rat glial cultures using the Nucleospin RNA plus kit (Macherey Nagel, France). cDNA was synthesized from $500 \mathrm{ng}$ of total RNA using the High-Capacity RNA-tocDNA Kit (Applied Biosystems, California). For real-time qPCR, we used $12.5 \mathrm{ng}$ of cDNA. The samples were run in duplicate on 96-well plates and then analyzed with 7500 v2.0 software (Applied Biosystems). The conditions of the thermal cycle were as follows: initial denaturation at $95^{\circ} \mathrm{C}$ for 40 cycles, denaturation at $95^{\circ} \mathrm{C}$, and hybridization and extension at $60^{\circ} \mathrm{C}$. Relative expression levels were determined according to the $\Delta \Delta \mathrm{Ct}$ (Ct: cycle threshold) method where the expression level of the mRNA of interest is given by $2^{-\Delta \Delta C T}$, where $\Delta \Delta C T=\Delta C$ t target mRNA $-\Delta C$ t reference mRNA (Gapdh, housekeeping gene) in the same sample. PCR experiments were performed with the 7500 Fast Real Time PCR System (Applied Biosystems), according to the manufacturer's recommendations. All reactions were performed using TaqMan Fast Universal PCR Mix (Applied Biosystems) and TaqMan Assays (Applied Biosystems) probes (see Table 2).

\subsection{1 | HEK 293 and N2a cell cultures and transfection}

Mouse neuroblastoma cells (N2a) obtained from Sigma were grown in DMEM supplemented with $10 \%(\mathrm{v} / \mathrm{v})$ heat-inactivated FBS, $2 \mathrm{mM}$ L-glutamine, $1 \%$ sodium pyruvate, and $50 \mathrm{U} / \mathrm{ml}$ penicillin/streptomycin (all from Invitrogen), at $37^{\circ} \mathrm{C}, 5 \% \mathrm{CO}_{2}$. Differentiation of $\mathrm{N} 2 \mathrm{a}$ cells was induced by treatment with $5 \mathrm{mM}$ cyclic adenosine monophosphate (cAMP, Sigma) in Opti-MEM (Invitrogen) for 5-7 days. Human embryonic kidney (HEK 293) cells (American Type Tissue

TABLE 2 Rat TaqMan probes used for qPCR analysis

\begin{tabular}{|c|c|c|}
\hline $\begin{array}{l}\text { Gene } \\
\text { name }\end{array}$ & Gene description & Probe ID \\
\hline Ntsr1 & Neurotensin receptor 1 & Rn01415846 \\
\hline Ntsr2 & Neurotensin receptor2 & Rn00575514 \\
\hline $\begin{array}{l}\text { Sort1/ } \\
\quad \text { Ntsr3 }\end{array}$ & Sortilin1/Neurotensin receptor3 & Rn01521847 \\
\hline Mcp1/ccl2 & Monocyte chemoattract ligand1 & Rn00580555 \\
\hline$\| 1 \beta$ & Interleukin1 $\beta$ & Rn00580432 \\
\hline 116 & Interleukin6 & $\mathrm{Rn} 01410330$ \\
\hline $\operatorname{Tnf} \alpha$ & Tumor necrosis factor $\alpha$ & Rn01525859 \\
\hline Gfap & Glial fibrillary acid protein & Rn01253033 \\
\hline $\mid b a 1$ & $\begin{array}{l}\text { Ionized calcium binding adaptor } \\
\text { molecule } 1\end{array}$ & Rn00574125 \\
\hline $\begin{array}{l}\text { Zif-268/ } \\
\text { erg1 }\end{array}$ & $\begin{array}{l}\text { Zing finger protein } 268 / \text { early growth } \\
\text { response protein } 1\end{array}$ & Rn00561138 \\
\hline Gapdh & $\begin{array}{l}\text { Glyceraldehyde-3-phosphate } \\
\text { dehydrogenase }\end{array}$ & $\mathrm{Rn} 01775763$ \\
\hline
\end{tabular}


Culture Collection ATCC, Manassas, Virginia) were grown in DMEM supplemented with factors but with $5 \%$ FBS. Transfection with a plasmid construct encoding rat NTSR2 DNA was carried out by using JetPEI (Polyplus Transfection, Illkirch, France) according to the manufacturer's instructions. Transfection took place in 12-well plates containing approximately 50,000 cells and $2 \mathrm{ml}$ Opti-MEM/well. For each well, $100 \mu \mathrm{l} \mathrm{NaCl} 150 \mathrm{mM}$ were mixed with $2 \mu \mathrm{l}$ JetPEl and $1 \mu \mathrm{g}$ DNA. Mixtures were incubated for $20 \mathrm{~min}$ at RT. Forty-four hours after transfection, cells were fixed with 4\% PFA in PB $0.12 \mathrm{M}$ for 20 min at RT and permeabilized as described above. Coverslips were incubated with rabbit NTSR2 antibody that was revealed with goat anti-rabbit IgG $(\mathrm{H}+\mathrm{L})$ highly cross-adsorbed AlexaFluor A488 (1:800, Life Technologies). Cell nuclei were labeled by DAPI.

\subsection{Whole cell extract, subcellular fractionation, and Western blot analysis}

Whole cell extracts were obtained from CTL untreated and CAMPtreated $\mathrm{N} 2 \mathrm{a}$ cultures that were homogenized in $50 \mathrm{mM}$ Tris- $\mathrm{HCl}$, $\mathrm{pH}$ 6,8, 5\% SDS, 6\% 2-mercaptoethanol, 10\% glycerol, and $4 \mathrm{mM}$ EDTA as we described previously (Ivanov et al., 2009). Frozen rat primary glial cell pellets were fractioned into cytosolic (CF) and membrane (MF) fractions using the ProteoExtraction Subcellular Proteosome Extraction Kit (Merck Millipore, Massachusetts) according to the manufacturer's instructions. The purity of the fractions was assessed by Western blotting with specific markers. The CF and MF were separated into aliquots and protein concentrations were determined by the DC protein assay (Bio-Rad, Hercules, California) according to the manufacturer's instructions. After $5 \mathrm{~min}$ boiling, Laemmli buffer with $6 \%$ 2-mercaptoethanol was added to aliquots containing $50 \mu \mathrm{g}$ protein which were analyzed on $10 \%$ sodium dodecyl sulfate (SDS)polyacrylamide gel electrophoresis (PAGE) using a MiniBlot system (Bio-Rad). After electrophoresis, the proteins were transferred onto Hybond-ECL nitrocellulose membranes (Amersham Biosciences, Buckinghamshire, UK) in transfer buffer (25 mM Tris, $192 \mathrm{mM}$ glycine, 20\% ethanol). Before blocking, the blots were stained with Ponceau red to visualize transfer efficiency. The blots were blocked in Tris-buffered saline (TBS and 0.05\% Tween20, TBS-T) containing 5\% milk for $1 \mathrm{~h}$ at RT and sequentially incubated overnight at $4^{\circ} \mathrm{C}$ in TBS-T containing $5 \%$ milk and the following primary antibodies (see Table 1): mouse monoclonal GAPDH and NTSR3 antibodies and rabbit anti-NTSR2 antibody. After incubation with primary antibodies, blots were washed three times for $5 \mathrm{~min}$ in TBS-T, incubated with corresponding horseradish peroxidase (HRP) secondary antibodies all from Jackson ImmunoReasearch: goat anti-mouse IgG-HRP (1/5000), rabbit anti mouse IgG $(H+L)$ HRP (1/2000), and goat anti-rabbit IgG FcHRP (1/2000), respectively, in TBS-T containing $5 \%$ milk for $1 \mathrm{~h}$ at RT and washed three times for 5 min each with TBS-T. Finally, proteins were detected using the ECL Prime Chemiluminescence Kit (Roche Diagnostics, Meylan, France) and visualized using chemiluminescence imaging system (UVITEC, Cambridge, UK).

\subsection{3 | Data analysis}

Acquisitions were performed using a confocal laser-scanning microscope (LSM 700, Zeiss, Jena, Germany) with a $\times 20$ or $\times 40$ oil objective and analysis of immunostaining images was performed using ZEN software (Zeiss). To visualize the whole hippocampus, the mosaic function was required. Z-stack function was also useful to determine precisely the co-expression of two markers in the same cells. Finally, ImageJ software (NIH) was used to quantify each immunolabeling. Pictures were binarized to 16-bit black and white images and a fixed intensity threshold was applied, defining each staining. Images were obtained with double averaging, frame size $1024 \times 1024$, and 1 AU pinhole for each channel. Images were processed using Adobe Photoshop software. For analysis of pharmacological treatments in CTL and inflamed glial cultures in 96-well plates, the InCell Analyzer 2200 (GE Healthcare, France) and Developer software (GE Healthcare) were used.

\subsection{Quantification of NTSR2 levels in GFAP ${ }^{+}$ cells on rat tissue}

The mean fluorescence intensity (mean gray value) was measured in three different hippocampal regions: dentate gyrus (DG), CA1, and CA3. Co-labeled NTSR2 and GFAP ${ }^{+}$cells were identified, and their fluorescence was estimated in Z-stack $\times 40$ acquired images on cell bodies and processes by drawing around them. A minimum of $n=200 \mathrm{GFAP}^{+}$cells were analyzed from 3 CTL and 3 PILO rats at each time point. We subtracted background fluorescence that was set in areas devoid of stained cells in the same sections; an average value of 3 such areas was obtained from every image. Data are presented as the mean percentage of fluorescence of NTSR2 ${ }^{+}$cells co-labeled with GFAP normalized to CTL (mean \pm SEM [standard error of the mean]). The same protocol was applied for IL1 $\beta$ quantification in different brain cell types.

\subsection{Quantification of NTSR2 levels in blood vessels on rat and mouse tissue}

The mean fluorescence intensity was measured in blood vessels of the DG and the lacunosum-moleculare (LM), by drawing and measuring around the inner and outer surface of large and small morphologically identified vessels. Fluorescence was estimated in Z-stack $\times 20$ mosaic images. All vessels from 3 CTL and 3 PILO 3D rats $(55$ and 79 vessels, respectively) or 3 CTL and 3 KA 7D mice (66 and 80 vessels, respectively) were quantified. We subtracted background fluorescence that was set in the stratum radiatum, in areas devoid of brain vessels in the same sections. An average value of 3 such areas was obtained from every image. Data are presented as the mean percentage of fluorescence of NTSR2+ cells co-labeled with GFAP normalized to CTL. 


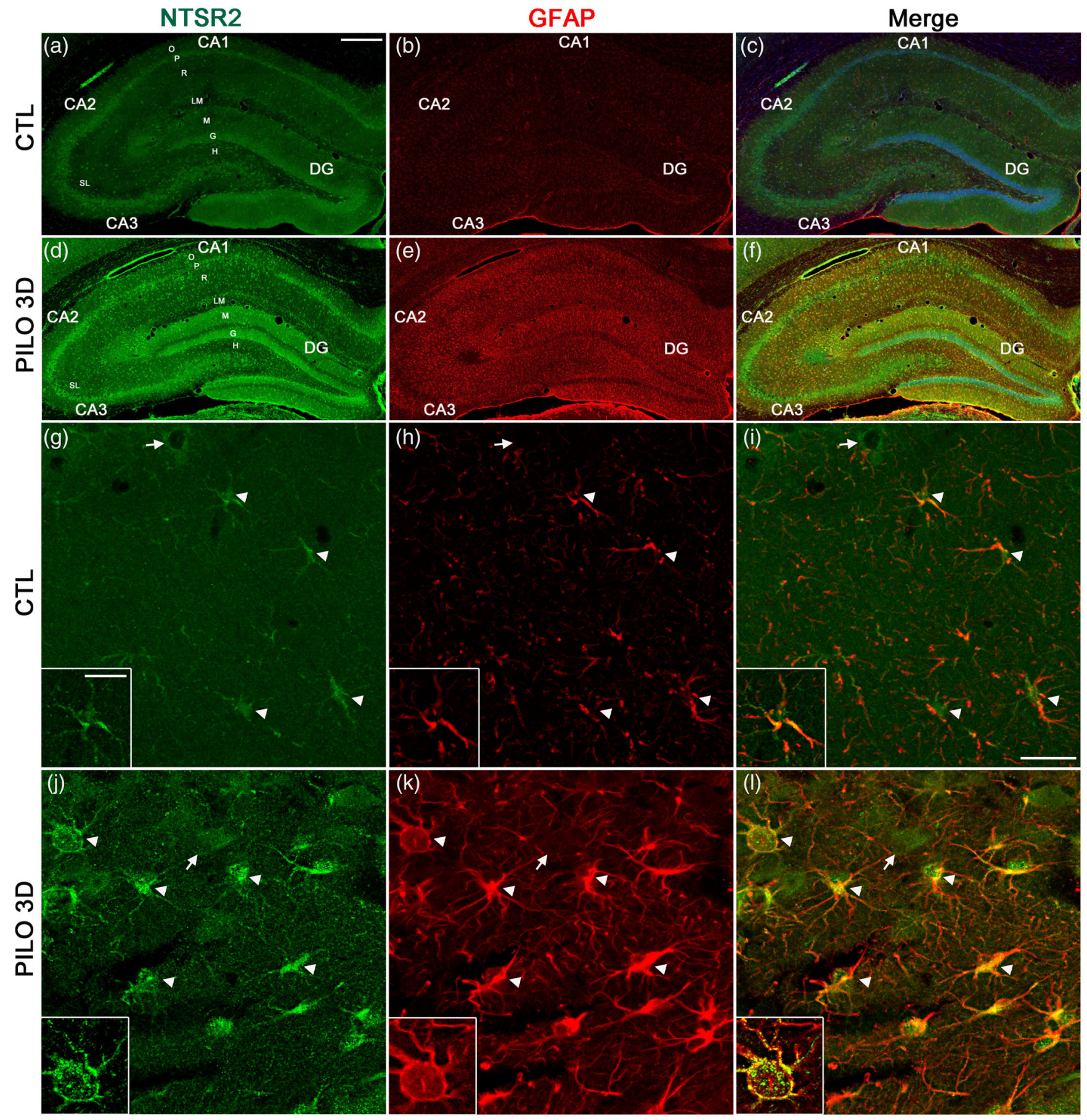

FIG URE 1 NTSR2 protein is expressed in rat hippocampal astrocytes and increases following pilocarpine-induced SE. NTSR2 (green) and GFAP (red) double immunolabeling was performed in CTL $(a-c, g-i)$ and pilocarpine-treated rats at day 3 post-SE (PILO 3D, $d-f$, $j-I)$. Cell nuclei were counterstained with DAPI (blue, $c$ and f). Merge corresponds to NTSR2/GFAP/DAPI (c and f). High magnification of the H of CTL (g-i) and PILO 3D (j-l) clearly shows NTSR2 immunolabeling in GFAP ${ }^{+}$astrocytes (see arrowheads), with stronger NTSR2 immunolabeling in PILO 3D compared with CTL animals. Note that non-astrocytic (GFAP-negative) NTSR2 ${ }^{+}$cells, most likely neuronal cells, are visible both in CTL and PILO 3D (g-I, see arrows). NTSR2 immunoreactivity is visible at the cell membrane, in the cell body and processes of astrocytes (see insets). In PILO 3D rats, NTSR2 immunolabeling displayed a more punctate pattern at the cell membrane as well as in processes (inset in $j$ and I) compared with CTL rats. Panels $i$ and I correspond to NTSR2/GFAP merged labeling. Scale bars: $450 \mu \mathrm{m}$ in a-f, $10 \mu \mathrm{m}$ in g-l, and $5 \mu \mathrm{m}$ in insets. O, stratum oriens; P, pyramidal neurons of CA1, CA2, and CA3; R, stratum radiatum; LM, stratum lacunosum-moleculare; M, molecular layer; DG, dentate gyrus; G, granule cell layer of the DG; H, hilus of the DG [Color figure can be viewed at wileyonlinelibrary.com] 


\subsection{6 | Quantification of NTSR2, GFAP, and Iba1 levels in CTL, inflamed, and NT-treated primary glial cultures}

Analyses were performed independently by NeuronExpert (Marseille, France). The mean fluorescence intensity of NTSR2, GFAP, and Iba1 in the cell bodies and processes was measured in double stained cells for NTSR2 and either GFAP or Iba1. For each condition in duplicate, 10 pictures per well were randomly taken from the whole well using InCell Analyzer 2200 with $\times 20$ magnification, from a total of $n=3$ independent experiments. We subtracted background fluorescence that was set in areas devoid of cells in every image. All the images were taken in the same conditions. Cell survival and area were automatically assessed using Developer software. Data are presented as the mean percentage of fluorescence of NTSR2 or GFAP/lba1 in the same cells, normalized to CTL. GFAP and Iba1 fluorescence levels were also compared with each other and presented as the mean percentage of fluorescence of each marker in different cells, normalized to GFAP.

\subsection{Statistical analysis}

All experiments were performed at least three times with different rat series or independent cultures. Student's $t$-test was used to compare two groups. ANOVA analysis followed by Tukey's post hoc test was used for multiple comparison. All data were expressed as the mean \pm SEM. Statistical significance was set at ${ }^{*} p<.05,{ }^{* *} p<.01$, and ${ }^{* * *} p<.001$.

\section{3 | RESULTS}

\subsection{Validation of the NTSR2 antibody}

We validated the specificity of the NTSR2 antibody by using transfection experiments followed by immunocytochemistry, RT-qPCR, and/or Western blot in different cell types from different species, in particular in human HEK 293, mouse N2a, and rat primary glial cultures (Figure S1). Both HEK 293 (Figure S1(a)) and N2a cells (Figure S1(b)) displayed stronger NTSR2 immunolabeling after transfection with a plasmid construct encoding rat NTSR2, compared with untransfected cells. Moreover, both types of cells displayed NTSR2 immunolabeling within the cell body and at the plasma membrane as expected for receptor localization. NTSR2 is known to increase with brain maturation (Lépée-Lorgeoux et al., 1999; Sarret et al., 1998). We thus assessed NTSR2 protein expression in N2a cells differentiated with CAMP ( $5 \mathrm{mM}$ ) compared with CTL and we observed a marked increase of NTSR2 fluorescence in both cell bodies and processes (Figure S1(c)). This increase in NTSR2 immunoreactivity was confirmed by both RT-qPCR and Western blot that showed increased NTSR2 mRNA and protein levels, respectively, in cAMP-treated N2a cells compared with untreated (Figure S1(d), left and middle panels). In Western blots, NTSR2 was detected as a single $45 \mathrm{kDa}$ band in
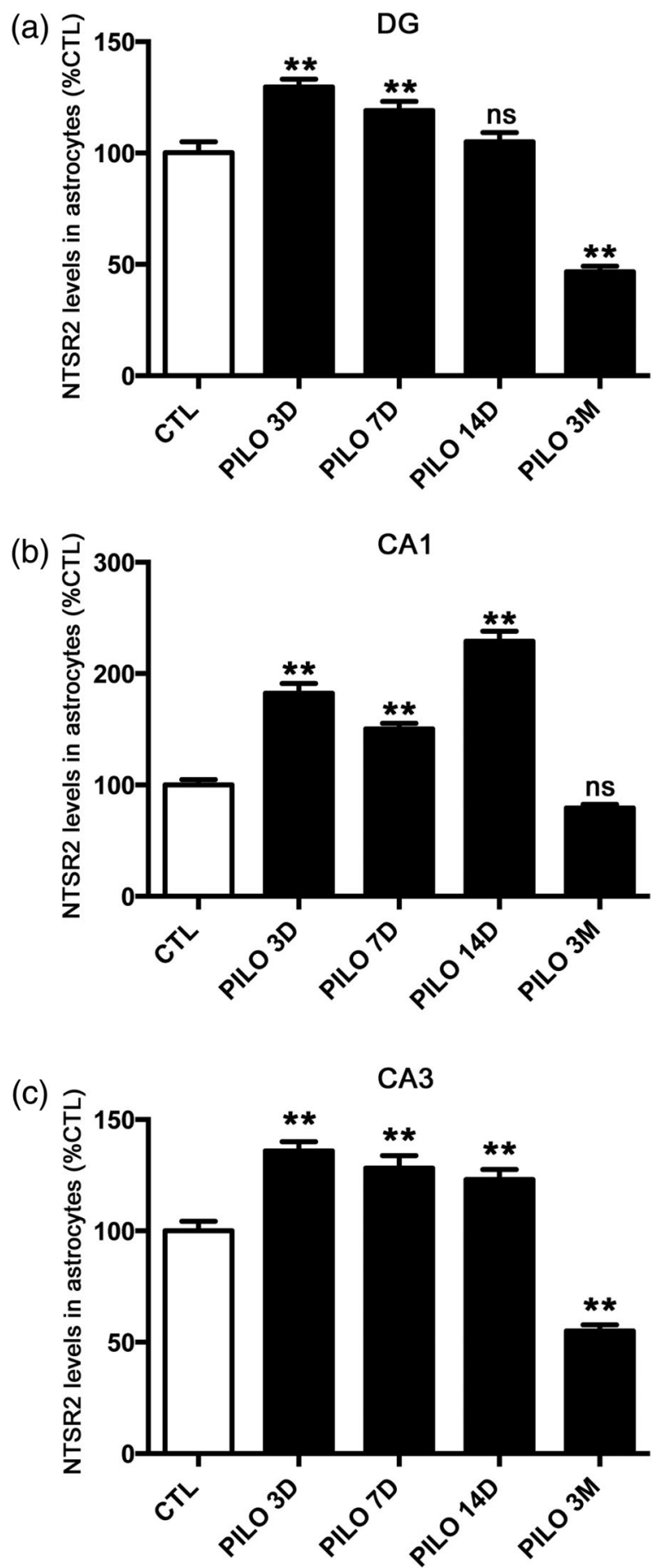

FIGURE 2 NTSR2 immunolabeling in rat hippocampal astrocytes increases at early time points and decreases at the chronic phase of pilocarpine-induced TLE. NTSR2 levels were quantified in cells labeled with both NTSR2 and GFAP and values were given as the mean \pm SEM as a percentage of CTL for each area. The highest increase for NTSR2 levels in astrocytes compared with CTL was observed in the DG (a) and CA3 (c) in PILO 3D rats and in CA1 (b) in PILO 14D. In PILO 3M, NTSR2 levels were significantly reduced in the DG and CA3 compared with CTL, but not in CA1. The number of rats per condition is 3 , and the number of cells per condition totals 200 . Asterisks indicate statistically significant differences: ${ }^{* *} p<.01$ (one-way ANOVA followed by Tukey's post hoc test) 
whole extract of CTL untreated or CAMP-differentiated N2a cells (Figure S1(d), middle panel). Rat primary glial cultures were fractionated into CF and MF and the same amounts $(50 \mu \mathrm{g})$ of CF and MF were analyzed by Western blot for specific markers: Glyceraldehyde3-phosphate dehydrogenase (GAPDH) as a major cytosolic marker (Baghirova et al., 2015; Sbai et al., 2021) and Sort1/NTSR3 as a membrane marker (Béraud-Dufour et al., 2009; Mazella et al., 2010; Sbai et al., 2021). Consistent with previous studies, GAPDH, NTSR2, and Sort1/NTSR3 proteins were detected as a single band with molecular weights of 38,45 , and $100 \mathrm{kDa}$, respectively (Dong et al., 2015; Sbai et al., 2021), in primary glial cells (Figure S1(d), right panel). We did not observe these bands when omitting the primary

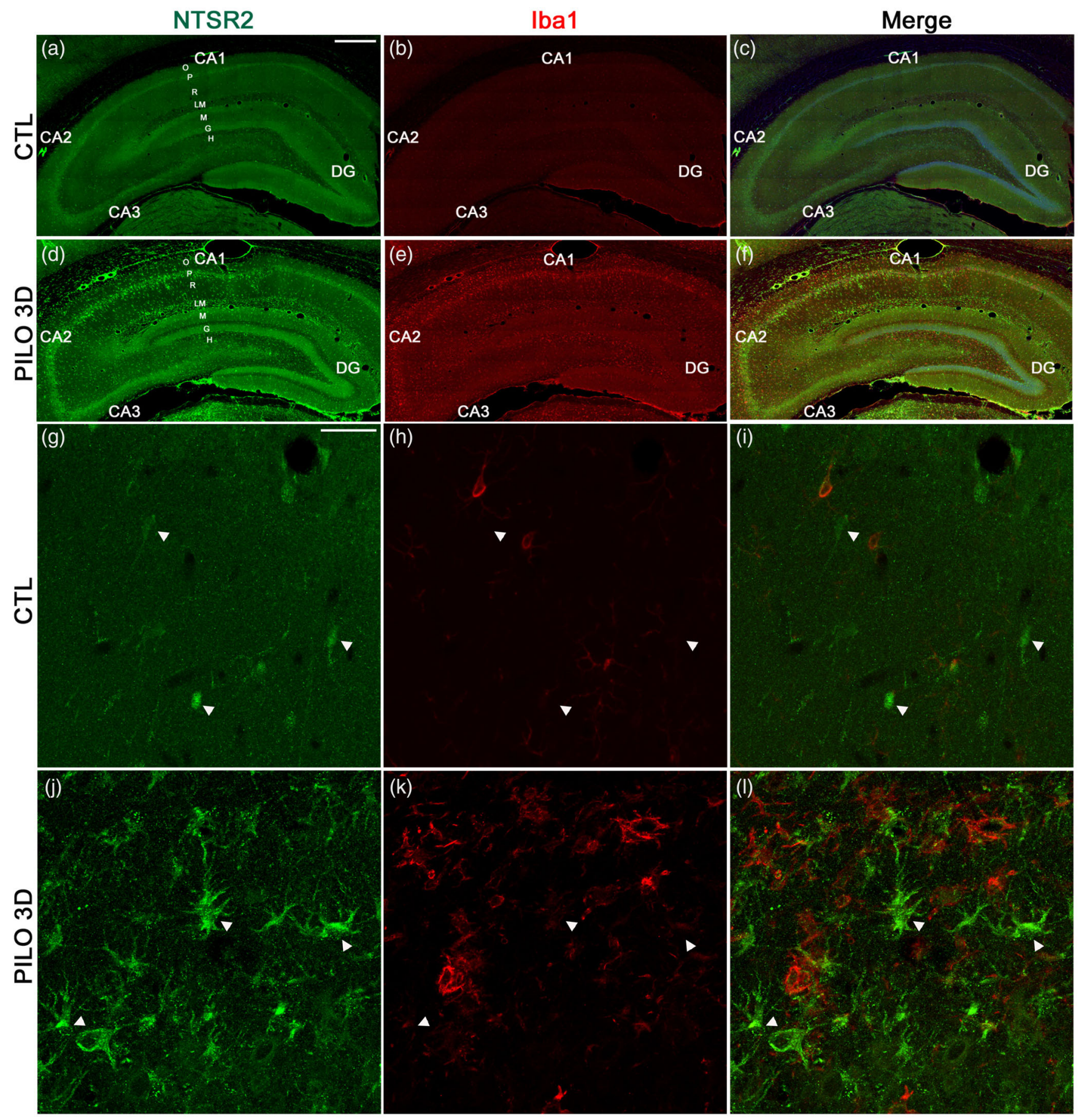

FIGURE 3 NTSR2 is not expressed in rat hippocampal microglial cells following pilocarpine-induced SE. NTSR2 (green) and Iba1 (red) microglia immunostaining was performed in CTL (a-c, g-i) and PILO 3D rats ( $d-f, j-l)$. Cell nuclei were counterstained with DAPI (blue, $c$ and $f$ ). Merge corresponds to NTSR2/lba1/DAPI (c and f). NTSR2 was not expressed in microglial cells in vivo since NTSR2 and Iba1 antibodies stain distinct cells as revealed by high magnification images (g-l, see arrowheads). Scale bars: $450 \mu \mathrm{m}$ in a-f and $10 \mu \mathrm{m}$ in g-I [Color figure can be viewed at wileyonlinelibrary.com] 
CTL
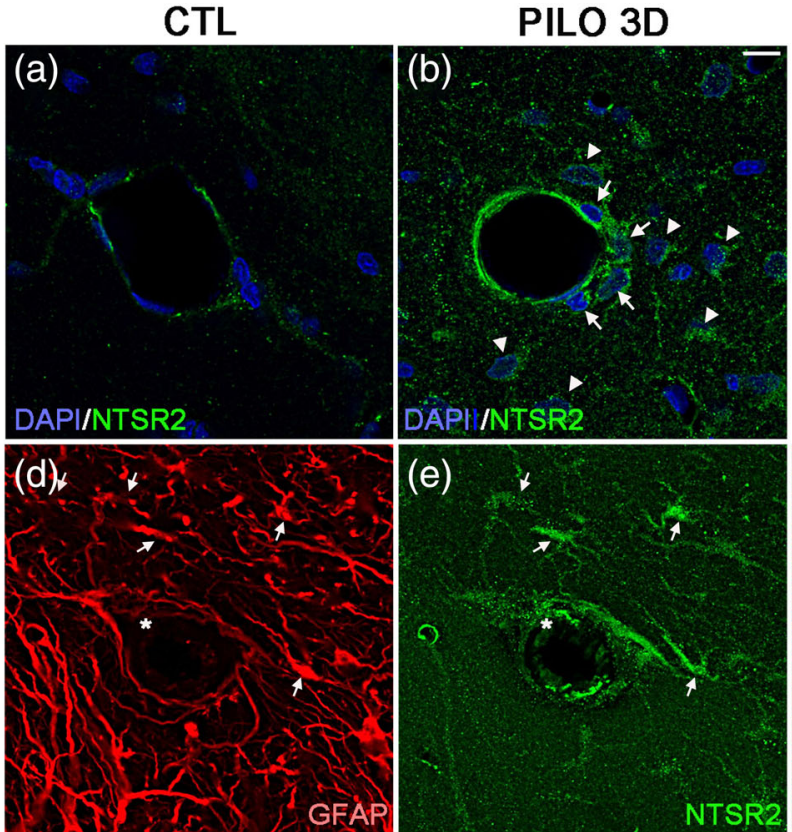

(c)
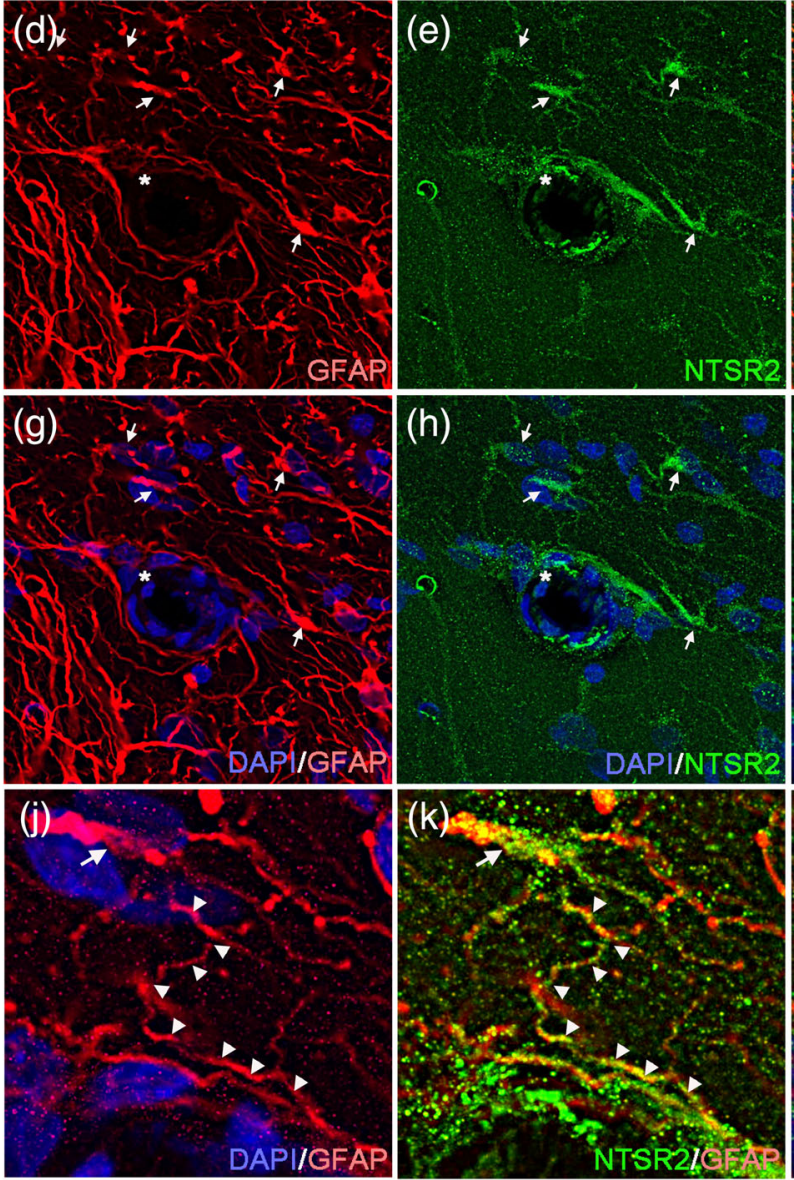

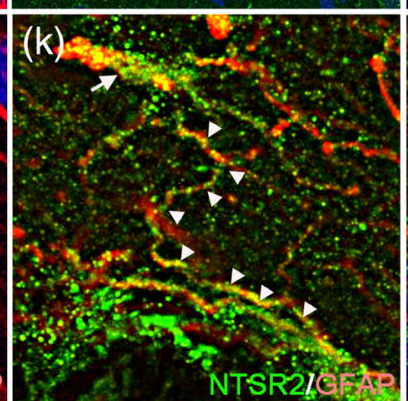

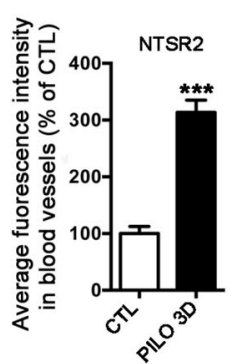
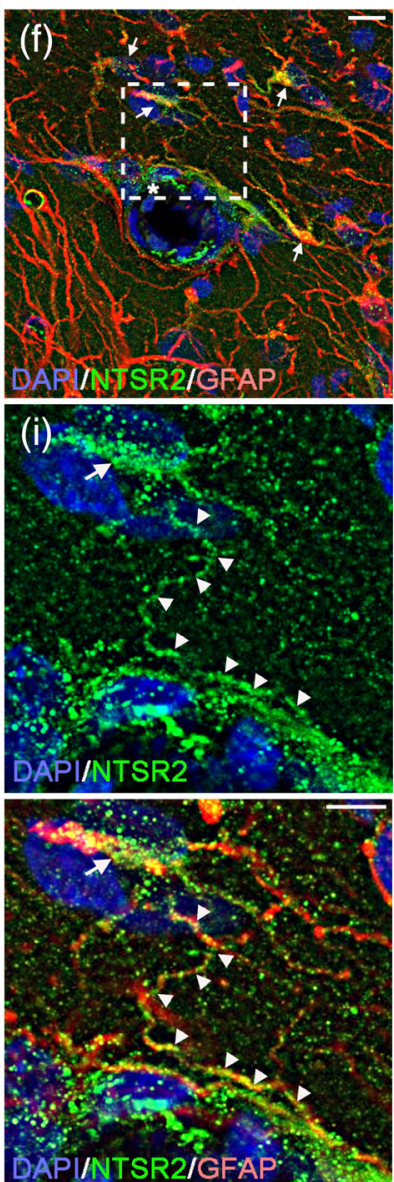

FIGURE 4 NTSR2 protein is expressed in rat blood vessels and increases following pilocarpine-induced SE. NTSR2 (green) immunostaining was performed in CTL (a) and PILO 3D rats

(b). Cell nuclei were counterstained with DAPI (blue). NTSR2 immunoreactivity was present in blood vessel cells of the LM with increased labeling in PILO 3D rats. In addition, several cells around these vessels displayed strong NTSR2 expression compared with CTL rats (arrows). Other dispersed cells in LM expressing NTSR2 are indicated (arrowheads). Average percentage of NTSR2 fluorescence intensity in DG and LM vessels in CTL and PILO 3D rats (c). Blood vessels of PILO 3D rats expressed significant NTSR2 levels compared with $\mathrm{CTL}$ vessels. Values are given as the mean \pm SEM as a percentage of CTL. Asterisks indicate statistically significant differences: ${ }^{* * *} p<.001$ (Student's t-test). GFAP (red, d, f, g, j, k, l) and NTSR2 (green, e, f, h, i, k, l) immunolabeling was performed in PILO 3D rats. All astrocytes (d-l, see arrows) around blood vessels expressed NTSR2. High magnification of the boxed-in area illustrated NTSR2 expression in the end-feet of astrocytes that project on blood vessels of the LM (i-I, arrowheads). In addition to astrocytes, other cells in and around blood vessels expressed NTSR2 (d, h, see stars). Scale bars: $20 \mu \mathrm{m}$ in a,b and $10 \mu \mathrm{m}$ in $\mathrm{d}-\mathrm{I}$ [Color figure can be viewed at wileyonlinelibrary.com] antibodies (data not shown). In primary glial cells, GAPDH is mainly present in the CF and at much lower levels in the MF (Figure S1(d), right panel). In contrast, both NTSR2 and Sort1/NTSR3 were present in the MF at higher levels compared with the CF (Figure S1(d), right panel), confirming their MF enrichment. All the above experiments confirmed that the NTSR2 rabbit polyclonal antibody used in the present study detected human, mouse, and rat NTSR2.

\subsection{NTSR2 protein is expressed in the rat hippocampus and increases following pilocarpine- induced SE}

Several lines of evidence suggest that NTSR2 mRNA is expressed in glial cells, namely astrocytes, in vitro and in vivo, including in the hippocampus (Lépée-Lorgeoux et al., 1999; Nouel et al., 1999; Walker et al., 1998). The NTSR2 protein was not expressed in hippocampal astrocytes (Sarret et al., 2003) but was recently described in astrocytes of the ventral tegmental area (Woodworth et al., 2018). We questioned the expression of NTSR2 protein in the hippocampus of CTL rats and its modulation in reactive astrocytes associated with epilepsy and neuroinflammation. In particular, we studied NTSR2 expression pattern in the hippocampus of rats at different stages following pilocarpine administration, a TLE model characterized by rapid astrocyte and microglial activation in the hippocampus (Shapiro et al., 2008). All rats that were injected with pilocarpine and that survived developed SE (mortality rate was around 25\%). From $10 \mathrm{~min}$ to $1 \mathrm{~h}$ following pilocarpine injection, rats exhibited limbic motor seizures every few minutes. After 3 weeks, spontaneous recurrent seizures started to appear that 
could last up to $60 \mathrm{~s}$, and developed into generalized seizures within the following days that persisted for the lifetime of the animals. These observations are in agreement with previous studies (Knake et al., 2009; Papageorgiou et al., 2011; Schmidt-Kastner \& Ingvar, 1994; Sharma et al., 2007).
We performed dual immunohistochemical labeling of NTSR2 (green) and glial fibrillary acidic protein (GFAP, red), a mature astrocyte marker (Dusart et al., 1991), at different stages following SE in pilocarpinetreated rats (Figure 1). In all experiments, NTSR2-immunohistochemical labeling was abolished when the anti-NTSR2 antibody was omitted (data

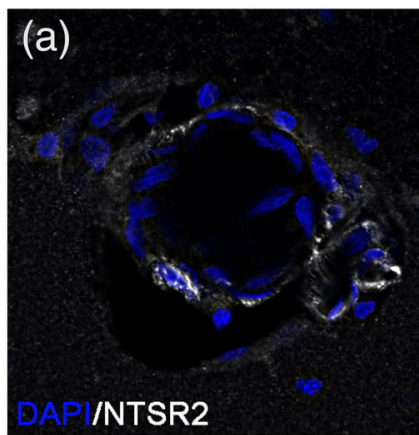

(e)

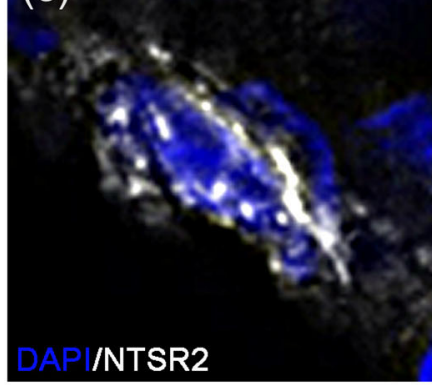

(i)

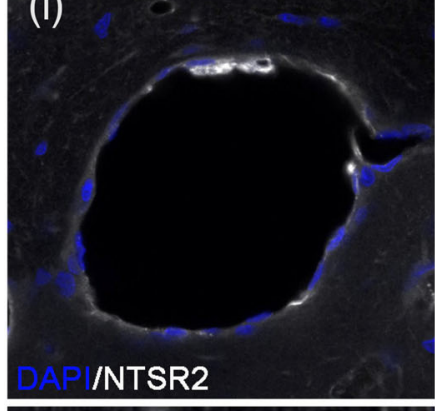

(m)

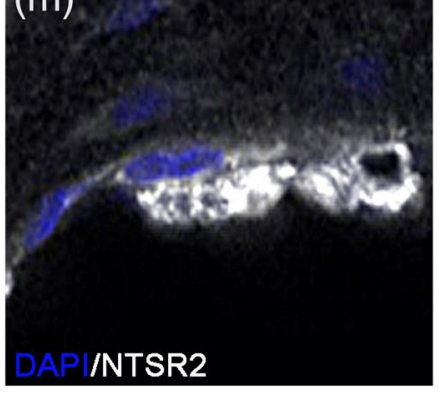

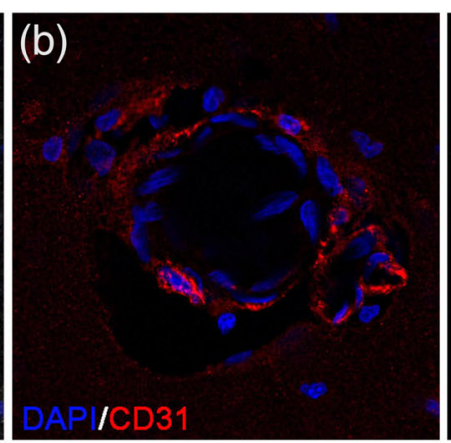

(f)

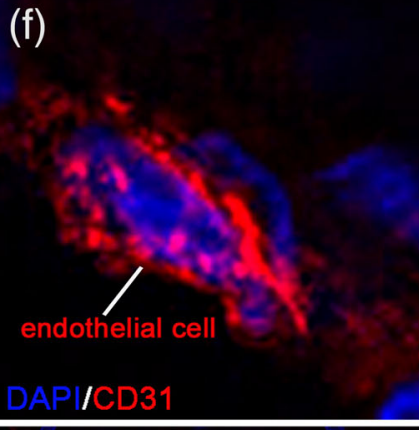

(j)

ICD31

(n)

PICD31

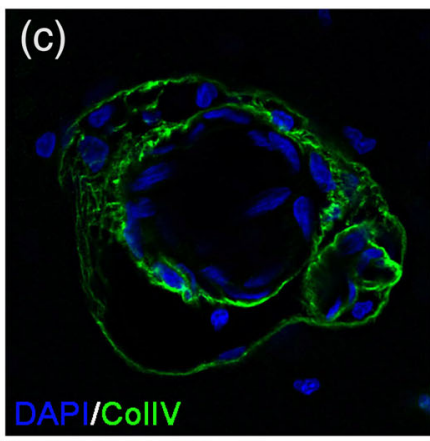

(g)

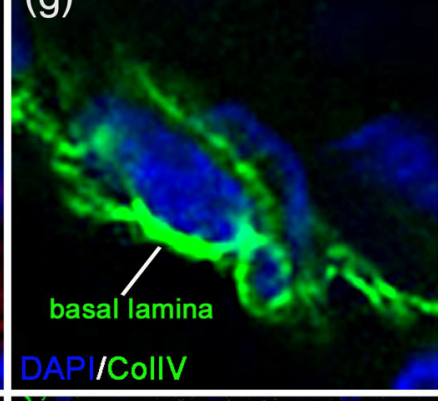

(k)

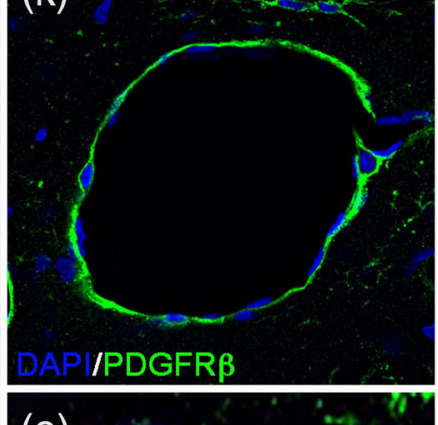

(o)

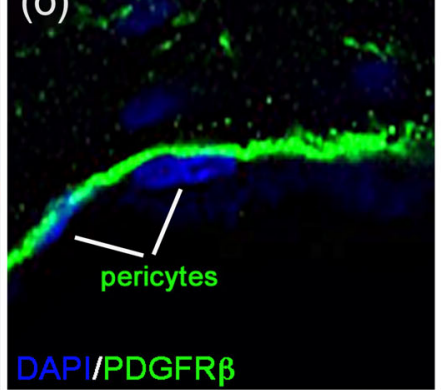

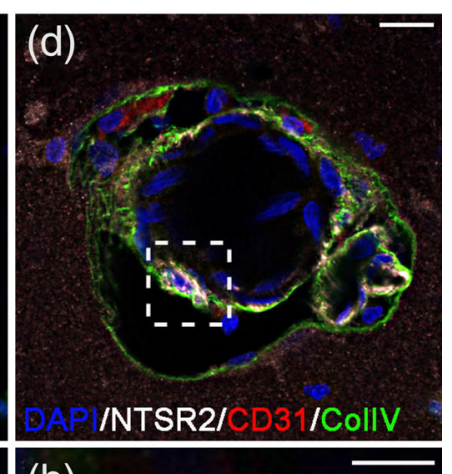

(h)

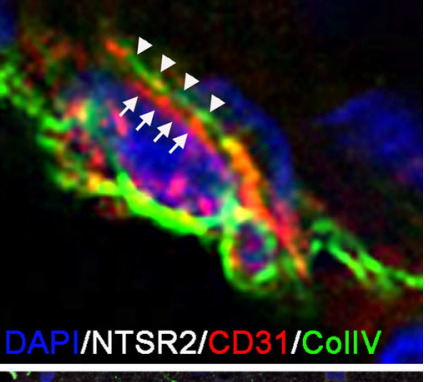

(I)
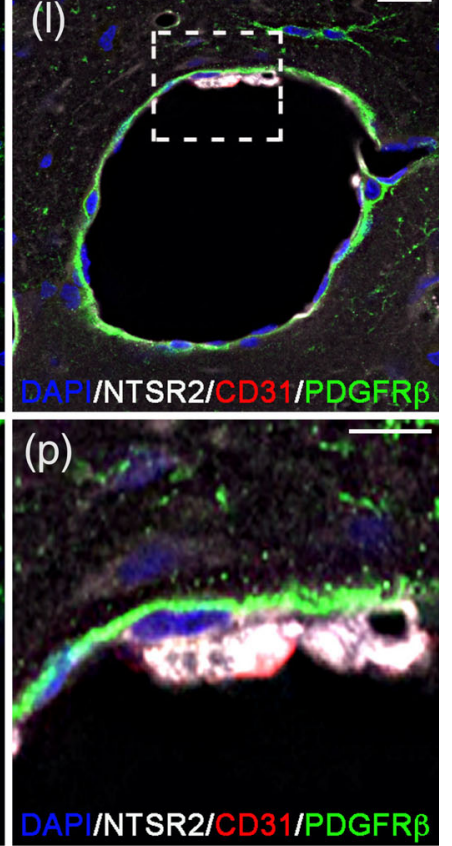

FIGURE 5 NTSR2 protein is expressed in rat blood vessel endothelial cells following pilocarpine-induced SE. NTSR2 (white), CD31 (red), and CollV (green) triple immunostaining was performed in PILO 3D rats (a-h). High magnification of the boxed-in area illustrates endothelial cells (red, arrows) and basal lamina (green, arrowheads), revealed with anti-CD31 and anti-CollV antibodies, respectively (e-h). NTSR2 labeling was mainly associated with endothelial cells as revealed with CD31 labeling. NTSR2 (white), CD31 (red) and PDGFR (green) immunostaining was performed in PILO 3D rats ( $i-p)$. High magnification of the boxed-in area illustrates endothelial cells (red) and pericytes (green), revealed with anti-CD31 and anti-PDGFR $\beta$ antibodies, respectively ( $m-p)$. Triple labeling (NTSR2/CD31/PDGFR $\beta$ ) confirmed NTSR2 expression in endothelial cells ( $m$, $n$, $p$ ) and faint or absent NTSR2 labeling in pericytes (o, p). Cell nuclei were counterstained with DAPI (blue). Scale bars: $20 \mu \mathrm{m}$ in a-d and i-I and $10 \mu \mathrm{m}$ in e-h and $\mathrm{m}-\mathrm{p}$ [Color figure can be viewed at wileyonlinelibrary.com] 
not shown). We chose to illustrate the results obtained at 3 days post SE (PILO 3D) with NTSR2 (Figure 1(a,d)) and GFAP (Figure 1(b,e)) labeling in control $(C T L)$ (Figure $1(a-c)$ ) and pilocarpine-treated rats (Figure $1(d-f)$ ). Indeed, in our conditions, the 3-day time point corresponds to strong astroglial inflammation, characterized by a dramatic increase of GFAP, in agreement with the temporal profile described by Shapiro et al. (2008). In sections from CTL rats, and at low magnification, NTSR2 immunolabeling was fairly homogeneous in all areas and layers of the hippocampus (Figure 1(a,c)) and showed a regional-specific and laminarspecific pattern within the hippocampus. Modest to moderate NTSR2 immunolabeling was found within all layers, including the stratum oriens $(O)$, stratum radiatum $(R)$, and the stratum lacunosum-moleculare $(L M)$ of the CA1-CA2-CA3 areas, the stratum lucidum (SL) of CA2-CA3, the molecular layer $(\mathrm{M})$, and the hilus $(\mathrm{H})$ of the dentate gyrus (DG) (Figure 1 (a)). The cell bodies of hippocampal pyramidal neurons (P) of CA1, CA2, and CA3, and granule cells $(G)$ of DG were moderately stained. The NTSR2 immunolabeling pattern was clearly different in PILO 3D compared with CTL rats. At low magnification, NTSR2 immunolabeling was characterized by a punctiform pattern in O, R, LM, and H. Strong NTSR2 immunolabeling was observed within all layers and areas, including the $\mathrm{O}, \mathrm{R}$, and the LM of the CA1-CA2-CA3 areas, the SL of CA2-CA3, the $M$, the cell bodies of $P$ of CA1-CA2-CA3 areas, and the $H$ of the DG (Figure 1(d,f)).

\section{3 $\quad$ NTSR2 protein is expressed in rat hippocampal astrocytes and increases following pilocarpine-induced SE}

At high magnification, all scattered $\mathrm{GFAP}^{+}$positive cells located in the $\mathrm{H}$ were clearly immunolabeled for NTSR2, both in CTL and PILO 3D rats. GFAP immunolabeling was clearly enhanced in astrocytes of the DG CA1, CA3, and the H of PILO 3D as compared with CTL rats, characteristic of astrocytic reactivity and neuroinflammation. All astrocytes, both in CTL and PILO 3D rats, as well as at all time points post-SE (data not shown), were NTSR2 positive. NTSR2 immunolabeling was markedly more intense in PILO 3D astrocytes in cell bodies, cell membrane and processes compared with CTL astrocytes (compare insets in $J$ and $L$ with insets in $g$ and i). While NTSR2 was fairly diffuse in CTL astrocytes (Figure 1(g-i), see insets), it appeared more punctiform in the astrocytes of the PILO 3D rats (Figure $1(j-l)$, see insets).

Since differences in NTSR2 and GFAP labeling intensity in astrocytes were observed consistently between CTL and PILO 3D, we conducted semi-quantitative analysis at various time points post-SE in the DG, CA1, and CA3 to determine the relative extent of these changes (Figure 2). In the DG, the mean NTSR2 levels were significantly increased in PILO 3D (129.7 $\pm 3.5 \%, 30 \%)$ and PILO 7D (119.1 $\pm 4.1 \%, 19 \%)$ when compared with CTL rats $(100 \pm 4.9 \% ; n=3$ rats; $p<.01$; Tukey's test), whereas no difference was found in PILO 14D (105.1 $\pm 4.1 \% ; n=3$ rats; $p>.05$; ANOVA). The mean NTSR2 levels were significantly decreased at 3 months post SE (PILO 3M) (46.7 $\pm 2.5 \%, 53 \% ; n=3$ rats; $p<.01$; Tukey's test) (Figure 2(a)). In CA1, the mean NTSR2 levels in astrocytes were significantly increased in
PILO 3D (182.3 $\pm 8.7 \%, 82 \% ; n=3$ rats; $p<.01$; Tukey's test), PILO 7D $(150.4 \pm 5 \%, 50 \%)$ and to a much higher extent in PILO 14D $(229.2 \pm 8.9 \%, 129 \%)$ as compared with CTL $(100 \pm 4.9 \% ; n=3$ rats; $p<.01$; Tukey's test). No difference was found in PILO 3M (79.3 $\pm 3.2 \% ; n=3$ rats; $p>.05$; ANOVA) (Figure 2(b)). In CA3, the mean NTSR2 levels in astrocytes were significantly increased in PILO 3D (135.9 $\pm 4.1 \%, 36 \%)$, PILO 7D (128.2 $\pm 5.6 \%, 28 \%)$ and PILO 14D $(123 \pm 4.5 \%, 23 \%)$ as compared with CTL $(100 \pm 4.3 \% ; n=3$ rats; $p<.01$; Tukey's test), whereas the mean NTSR2 levels in astrocytes were significantly decreased in PILO $3 \mathrm{M}(55 \pm 2.8 \%, 45 \% ; n=3$ rats; $p<.01$; Tukey's test) (Figure 2(c)). Our data show that NTSR2 protein is expressed in hippocampal astrocytes of CTL rats and its expression is differentially regulated in distinct hippocampal regions following pilocarpine-induced seizures.

\subsection{NTSR2 protein is not expressed in rat microglial cells in vivo following pilocarpine- induced SE}

We next sought to determine whether NTSR2 is also expressed and/or regulated in microglial cells, that also contribute to inflammation in pilocarpine-induced seizures in rats. To this end, we performed double immunolabeling of NTSR2 (Figure 3(a,d), green) and the ionized macrophage and microglia specific calcium-binding adaptor molecule-1 (Iba1) (Ohsawa et al., 2004) (Figure 3(b,e), red) in CTL and pilocarpine-treated rats at different time points post-SE, in the DG, CA1, and CA3. Similar to GFAP, increased Iba1 immunolabeling, characteristic of inflammation, was observed in hippocampal microglial cells of PILO 3D rats as compared with CTL rats (Shapiro et al., 2008). High magnification images from CTL rats (Figure 3(g-i)) and PILO 3D (Figure 3(j-l)), clearly showed that the NTSR2 and Iba1 antibodies stained distinct cells in the $\mathrm{H}$ of the DG (Figure 3(g-l), see arrowheads), and in all other subfields of the hippocampus (data not shown), indicating that NTSR2 is not expressed in microglial cells in vivo.

\section{5 | NTSR2 protein is expressed in rat blood vessels and increases following pilocarpine-induced $\mathrm{SE}$}

Immunohistochemical analysis of hippocampal slices revealed that the NTSR2 protein is expressed in blood vessels of the LM of CTL and PILO 3D rats (Figure 4(a,b), in green). The pattern of NTSR2 immunolabeling was clearly altered in and around the blood vessels of PILO 3D rats (Figure 4(b)), compared with that observed in CTL rats (Figure 4(a)). The expression of NTSR2 increased in the blood vessels of the LM of PILO 3D. Furthermore, we observed several cells in the close vicinity of these vessels (see arrows), and other cells sparsely distributed around the blood vessels (see arrowheads), which displayed also high NTSR2 immunolabeling with a punctate pattern. Because differences in NTSR2 labeling intensity in the blood vessels were observed consistently between CTL and PILO animals, we conducted semi-quantitative analysis in CTL and PILO 3D rats to determine the relative extent of these changes (Figure 4(c)). In the LM 
and DG, the mean intensities of blood vessel labeling for NTSR2 were significantly increased in the PILO 3D animals (313.6 $\pm 21.4 \%, 213 \%$; $p<.001$, Student's $t$-test), when compared with CTL rats (100 $\pm 12.2 \%$ ). Thus, these data indicate upregulation of NTSR2 protein expression in the blood vessels during pilocarpine-induced seizures.

\subsection{NTSR2 protein is expressed in rat astrocytic end-feet and endothelial blood vessel cells following pilocarpine-induced SE}

Since all GFAP-labeled cells were also labeled for NTSR2, we performed high magnification confocal microscopic analysis to reveal the cellular compartments of astrocytes that were immunolabeled for NTSR2 (Figure 4(d-I)). We used GFAP to label astrocytes, astrocytic processes, and end-feet. Double immunofluorescence showed high NTSR2 expression in all reactive hypertrophic astrocytes (expressing high levels of GFAP) that were located around the blood vessels of the LM (Figure 4(d-h), yellow, see arrows) in PILO 3D rats, when NTSR2 expression reached its peak. In addition, high magnification images revealed that astrocytic processes as well as their end-feet that project on blood vessels, were also strongly immunolabeled for NTSR2 (Figure 4(i-I), yellow, see arrowheads). Nevertheless, other cells that constitute the blood vessels that were not GFAP-positive also expressed high levels of NTSR2 (see stars in Figure 4(d-h)). These vessels are constituted by endothelial cells, surrounded by a basal lamina, pericytes, astrocytic end-feet, microglia and neurons that collectively form the blood-brain barrier (BBB) (ElAli et al., 2014; Uzunalli et al., 2019). In order to determine the identity of the NTSR2-expressing cells in blood vessels, we used antibodies directed against the endothelial cell adhesion molecule CD31 and pericyte marker platelet derived growth factor receptor-beta, PDGFR $\beta$ (Uzunalli et al., 2019). The basal lamina was revealed using an antibody against Collagen IV (CollV) (Figure 5). We first examined whether endothelial cells expressed NTSR2. To this end, we performed NTSR2, CD31, and CollV triple immunolabeling in PILO 3D rats (Figure 5(a-h)). High magnification images of LM blood vessels revealed that NTSR2 was expressed in endothelial cells since both NTSR2 and CD31 stained the same cells (Figure 5(e-h)). Endothelial cells displayed a punctiform NTSR2 immunolabeling pattern. Note that the CollV immunolabeling (Figure 5(g-h), see arrowheads) was closely apposed to CD31 labeling (Figure 5(h), see arrows), as endothelial cells were surrounded by basal lamina. Blood vessel pericytes are present on the abluminal surface of the endothelium and in direct contact with endothelial cells while separated by the basement membrane (Armulik et al., 2011). To determine whether NTSR2 was expressed in pericytes, NTSR2, CD31, and PDGFR $\beta$ triple immunolabeling was carried out in PILO 3D rats (Figure 5(i-p)). High magnification images showed that NTSR2 was faintly expressed in PDGFR $\beta$ labeled pericytes, as compared with strong labeling of CD31-labeled endothelial cells (Figure $5(m-p)$ ). The faint NTSR2 immunolabeling displayed by pericytes is more diffuse than that showed for astrocytes and endothelial cells (Figure 5(o-p)). Thus, our results indicated that NTSR2 is not only increased in its expression in reactive astrocytes, but also in endothelial cells, in association with neuroinflammation.

\section{7 | NTSR2 protein is also expressed in mice hippocampal astrocytes, astrocytic end-feet, and endothelial cells and increases following kainate- induced SE}

In order to evaluate whether increased NTSR2 expression was specific to the rat pilocarpine TLE model or may occur in other TLE models, we injected KA to adult mice, generating SE and subsequent damage to the CA3 subfield, along with injury to the CA1 and $\mathrm{DG} /$ hilar region. All mice developed spontaneous recurrent seizures within 5 days, in agreement with previously published studies (Mouri et al., 2008) and displayed sustained neuroinflammation with astrogliosis post-KA-induced SE (Chen et al., 2005; M. Ding et al., 2000).

We performed dual immunohistochemical labeling of NTSR2 (green) and GFAP (red) in CTL and KA-injected mice 1 week post-SE (KA 7D), when animals displayed sustained neuroinflammation (Figure S2). In CTL mice, and at low magnification, NTSR2 immunolabeling was fairly homogeneous in all hippocampal areas (Figure S2(a,c)) and showed a regional-specific and laminar-specific pattern. Modest to moderate NTSR2 immunolabeling was found within all layers (Figure S2(a)). The NTSR2 immunolabeling pattern was

TABLE 3 Ratios of mRNAs encoding inflammatory molecules in the hippocampus of PILO 3D rats compared with CTL

\begin{tabular}{lllll}
\hline mRNA & $\begin{array}{l}\text { Rat1PILO3D/ } \\
\text { CTL mRNA ratio }\end{array}$ & $\begin{array}{l}\text { Rat2PILO3D/ } \\
\text { CTL mRNA ratio }\end{array}$ & \multicolumn{2}{l}{$\begin{array}{l}\text { Rat3PILO3D/ } \\
\text { CTL mRNA ratio }\end{array}$} \\
\hline IL1 $\beta$ & 4.65 & 16.2 & 3.71 & 8.19 \\
\hline IL6 & 1.43 & 3.3 & 1.41 & 2.05 \\
\hline TNF $\alpha$ & 3.95 & 5.73 & 2.47 & 4,05 \\
\hline GFAP & 19,29 & 18.54 & 8.34 & 15.39 \\
\hline Iba1 & 6.62 & 4.74 & 2.95 & 4.77 \\
\hline
\end{tabular}

Note: RT-qPCR analyses were performed to assess the levels of mRNAs encoding the pro-inflammatory cytokines IL1 $\beta$, IL6, and TNF $\alpha$ and inflammatory markers GFAP and Iba1. Values are the mean of 3 PILO 3D rats normalized to CTL (mean value calculated from 4 rats normalized to the corresponding internal standard GAPDH). Results show a clear induction in all 3D PILO rats of the mRNAs encoding the pro-inflammatory cytokines and neuroinflammation markers. 
clearly enhanced in KA 7D compared with CTL mice (Figure S2(d)). At low magnification, NTSR2 immunolabeling was characterized by a punctiform and filamentous pattern in O, R, LM, and $\mathrm{H}$. Strong NTSR2 immunolabeling was observed within all hippocampal layers (Figure S2 $(d, f))$. This strong increase of NTSR2 is associated with induced GFAP immunolabeling (compare Figure S2(b) with Figure S2(e)). At high magnification, all $\mathrm{GFAP}^{+}$cells of the hippocampus were double immunolabeled for NTSR2, as illustrated in the H, both in CTL (Figure S2(g-i)) and KA 7D (Figure S2(j-I)). In KA 7D, NTSR2 immunolabeling was remarkably more intense, in astrocytic cell membranes and processes. The staining of NTSR2 and Iba1 in CTL and KA 7D mice sections (where a dramatic increase of Iba1 is observed) were clearly distinct (Figure S3), indicating that NTSR2 was not expressed in mice microglial cells.

An increase of NTSR2 immunolabeling was also observed in the blood vessels of KA-treated mice (Figure S4(a,b)). Other cells around these vessels, likely perivascular astrocytes projecting their processes (indicated by arrows and asterisks), displayed moderate to strong NTSR2 labeling when compared with CTL (arrowheads) (Figure S4(b)). Semi-quantitative analysis in CTL and KA 7D mice showed that the mean intensities of NTSR2 labeling around the blood vessels in the LM and DG were significantly increased in the KA 7D $(267.5$ $\pm 21.7 \%, 167 \% ; p<.001$, Student's $t$-test), when compared with CTL animals (100 $\pm 7.1 \%$ ) (Figure S4(c)). In KA 7D mice sections, reactive $\mathrm{GFAP}^{+}$astrocytes around the LM blood vessels showed strong NTSR2 expression (Figure S4(d-h), see arrows). At high magnification, astrocytic processes and end-feet were also strongly immunolabeled for NTSR2 (arrowheads), as well as other cells on the luminal side of the blood vessels (stars) (Figure S4(i-I)). Triple immunolabeling of NTSR2, CD31, and CollV in KA 7D mice showed that NTSR2 was strongly expressed in endothelial cells (Figure S5(a-h)), while triple NTSR2, CD31, and PDGFR $\beta$ immunolabeling confirmed NTSR2 specific expression in endothelial cells and showed faint, rather diffused expression in pericytes (Figure S5(i-p)). Collectively, similar to PILO animals, our data showed that NTSR2 expression is increased in astrocytes and blood vessels in association with neuroinflammation in KA-treated animals.

\section{8 | Changes in proinflammatory cytokines and inflammation markers following PILO-induced SE}

Our results suggest a link between NTSR2 regulation and neuroinflammation. There is evidence that in addition to the induction of neuroinflammation markers such as GFAP and Iba1 (including this study), PILO-induced SE is associated with induction of proinflammatory factors (Vieira et al., 2014). We thus assessed whether this was the case in our PILO model for major cytokines such as IL1 $\beta$, IL6, and TNF $\alpha$. We first used RT-qPCR to compare the mRNA expression levels of these cytokines at PILO 3D, in parallel with GFAP and Iba1 neuroinflammation markers. Our results (Table 3 ) clearly indicate that in all animals studied, there is strong induction, from 2-fold to
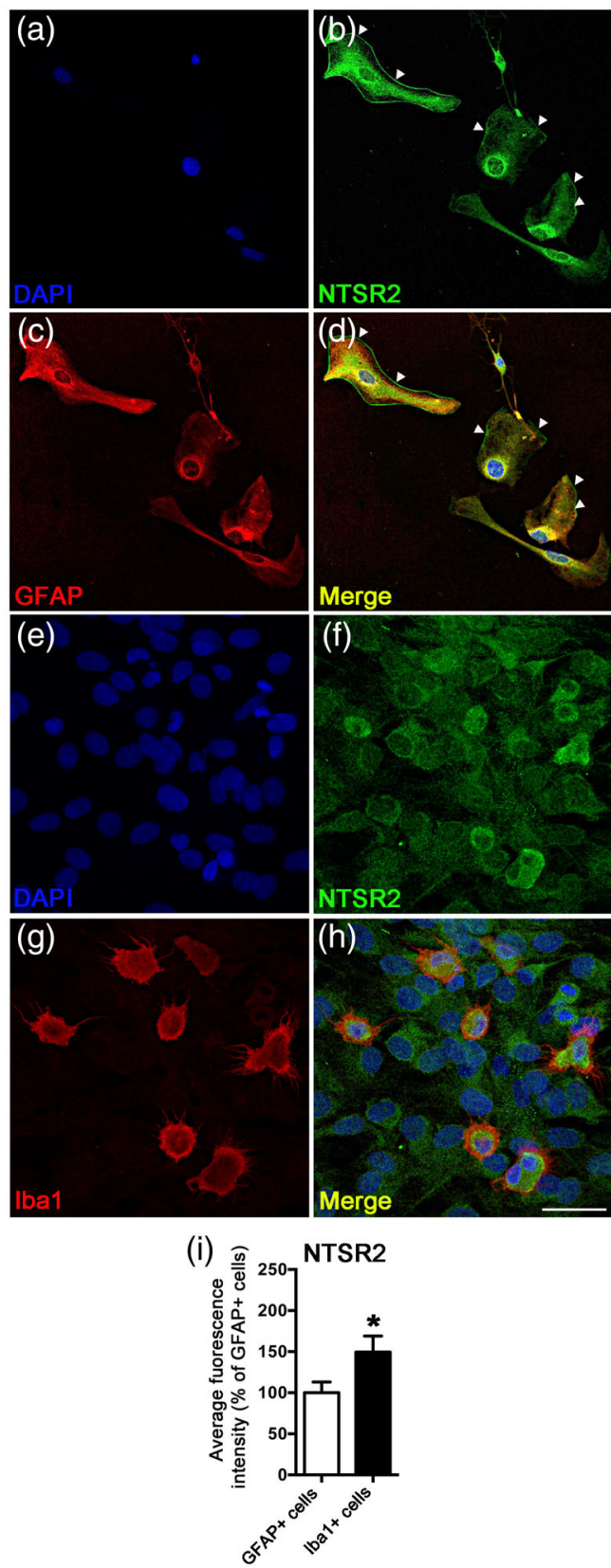

FIG URE 6 NTSR2 protein is expressed in rat primary cultured glial cells. Double NTSR2 (green, b) and GFAP (red, c) immunofluorescence shows that astrocytes from rat primary glial cultures express NTSR2 within the cell body and at the plasma membrane (b, $d$, see arrowheads). The strong immunostaining found in the cell body likely corresponds to the Golgi apparatus. NTSR2 (green, $\mathrm{f}$ ) was also expressed in microglial cells from rat primary glial cultures, identified by lba1 (red, g). Cell nuclei were counterstained with DAPI (blue, a, b, d \& e, f, h). Merge corresponds to superimposition of DAPI, NTSR2, and GFAP (d), or DAPI, NTSR2 and lba1 staining (h). The fluorescence intensity of NTSR2 labeling in $\mathrm{GFAP}^{+}$cells was compared with that of Iba $1^{+}$cells (i). The average intensity of NTSR2 was significantly higher in microglial cells compared with astrocytes (h). Values are given as the mean \pm SEM normalized to $\mathrm{GFAP}^{+}$cells. Asterisk indicates statistically significant difference: ${ }^{*} p<.05$ (Student's t-test). Scale bar: $10 \mu \mathrm{m}$ [Color figure can be viewed at wileyonlinelibrary.com] 
FIGURE 7 Inflammation differentially affects NTSR expression in rat primary glial cultures. Histograms showing RTqPCR quantification of the inflammatory cytokines IL1 $\beta$ (a) and MCP-1/ccl2 mRNA levels (b), after 1, 6, and $24 \mathrm{~h}$ treatment with either IL1 $\beta(10 \mathrm{ng} / \mathrm{ml})$ or LPS $(1 \mu \mathrm{g} / \mathrm{ml})$. MCP-1/CCL2 protein in the supernatants of cultured glial cells was assessed by ELISA after $24 \mathrm{~h}$ treatment with either IL1 $\beta$ or LPS (c). IL1 $\beta$ mRNA was induced after 1 and $6 \mathrm{~h}$ treatment with LPS, and MCP-1/ccl2 mRNA was induced after $6 \mathrm{~h}$ treatment with either IL1 $\beta$ or LPS. Accordingly, MCP-1/CCL2 protein was increased in primary glial cultures after IL1 $\beta$ or LPS treatment. RTqPCR analyses show that NTSR2 (d) and Sort1/NTSR3 (e) mRNAs were induced after $1 \mathrm{~h}$ treatment with IL1 $\beta$ or LPS, while NTSR1 mRNA levels were not modulated (f). Values for $a, b, d, e, f$ are given as the mean \pm SEM normalized to CTL. Asterisks indicate statistically significant differences: ${ }^{*} p<.05$,

${ }^{* *} p<.01$ (one-way ANOVA followed by Tukey's post hoc test)

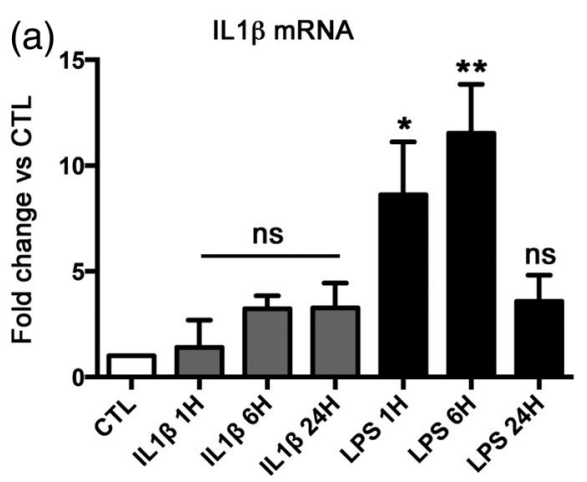

(d) NTSR2 mRNA

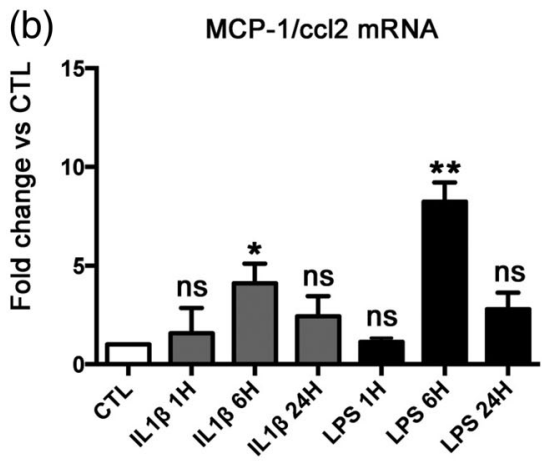

(c)

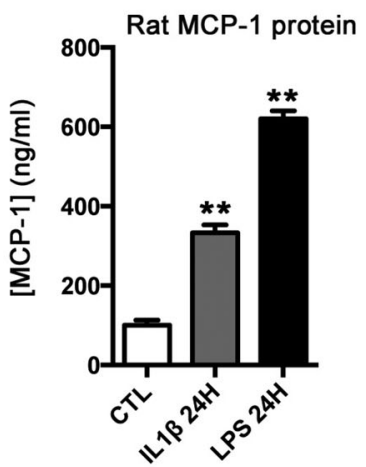

(e)
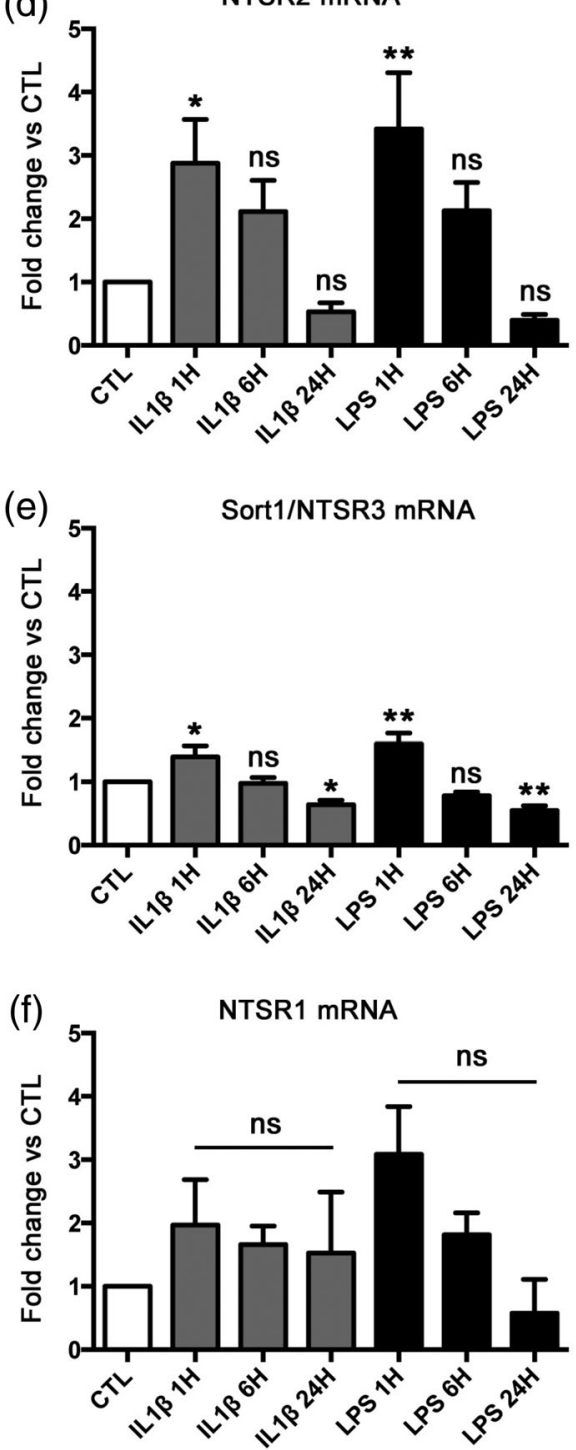

8.2-fold on average, for the mRNAs encoding pro-inflammatory cytokines, and 4.8-fold to 15.4-fold on average for those encoding inflammatory markers. Among the three major cytokines we studied, IL1 $\beta$ appears the most induced.

To further confirm these results, we compared IL1 $\beta$ protein expression in CTL and PILO 3D rat brain tissue sections using immunohistochemistry (Figure S6). In sections from CTL rats, modest to moderate IL1 $\beta$ immunolabeling was observed in the enthorinal cortex (EC) (Figure S6(a)), DG (Figure S6(c)), and CA1 area (Figure S6(e)). In sections from PILO 3D, IL1 $\beta$ immunolabeling was strongly increased in cell bodies with processes reminiscent of the glial phenotype located in the EC (Figure S6(b), see arrows), LM, G, and H of the DG (Figure S6(d), see arrows), the O, R (data not shown), and the $P$ of area CA1, (Figure S6(f), see arrows). Several non-glia-like cells were also strongly immunolabeled for IL1 $\beta$ in the EC of PILO 3D (Figure S6(b), see arrowheads) compared with CTL rats (Figure S6(a), see arrowheads). At high magnification, increased IL1 $\beta$ immunolabeling was also observed at the border of vessels (Figure S6, inset) located in the EC of PILO 3D. In
CTL rats, strong IL1 $\beta$ immunolabeling was observed in scattered hilar neuronal cells (mossy and/or interneurons) in the $\mathrm{H}$ (see stars in Figure S6(c)), while in PILO 3D these cells were no longer present probably due to neurodegeneration known to occur in this model (Boulland et al., 2007; reviewed in Houser, 2014). In PILO 3D rats, IL1 $\beta$ immunolabeling displayed a more punctate pattern in the cell bodies as well as in processes (inset in b, $d$, and f) compared with CTL rats (inset in a, c, and e).

Since differences in IL1 $\beta$ immunolabeling intensity were observed consistently between CTL and PILO rats, we first carried out double immunolabeling to identify the cell types with increased IL1 $\beta$ GFAP and MAP2 specific markers to identify mature astrocytes and neurons, respectively (Figure S7). Second, we conducted semiquantitative analysis at 3 days post-SE in the EC, DG, and CA1 to determine the relative extent of these changes (Figure S8). IL1 $\beta$ (green, Figure S7(b)), and GFAP (red, Figure S7(c)) double immunolabeling shows that the increased IL1 $\beta$ expression occurred within the cell bodies and processes of astrocytes located in the EC, 
DG, and CA1. In addition, IL1 $\beta$ (green, Figure S7(d)) and MAP2 (red, Figure S7(e)) double immunolabeling shows that increased IL1 $\beta$ expression occurred also within neurons located in the EC of PILO 3D. Double immunolabeling shows a colocalization of IL1 $\beta$ (green, Figure S7(g)) and GFAP (Figure S7(h)) at the blood vessels of the EC of PILO 3D rats. In addition, we also observed several cells immunolabeled for IL1 $\beta$ and GFAP around these vessels. Astrocytic processes, as well as their end-feet that project on blood vessels, were also strongly immunolabeled for IL1 $\beta$ (Figure S7(i), yellow, see arrowheads).

Semi-quantitative analysis (Figure S8) revealed that in the EC, the mean IL1 $\beta$ levels were significantly increased in astrocytes $(202.8 \%$, Figure S8(a)), neurons (188.5\%, Figure S8(b)), and vessels $(180.2 \%$,
Figure S8(c)) of PILO 3D when compared with CTL rats (100\%). Similarly, in the hippocampus, the mean IL1 $\beta$ levels in astrocytes were also significantly increased in the DG (163.11\%, Figure S8(d)) as well as in area CA1 (192.10\%, Figure S8(e)) in PILO 3D when compared with CTL rats. Thus, we showed that IL1 $\beta$ is induced in vivo in the same cell types and structures as those observed for NTSR2 induction. Our study showed that PILO rats displayed increased expression of inflammatory molecules, as reported in different epileptic models (De Simoni et al., 2000; Vieira et al., 2014; Voutsinos-Porche et al., 2004), and justify using IL1 $\beta$ as a proinflammatory factor to study the effects of neuroinflammation on the regulation of NTSR2 expression in primary glial cultures. (a)

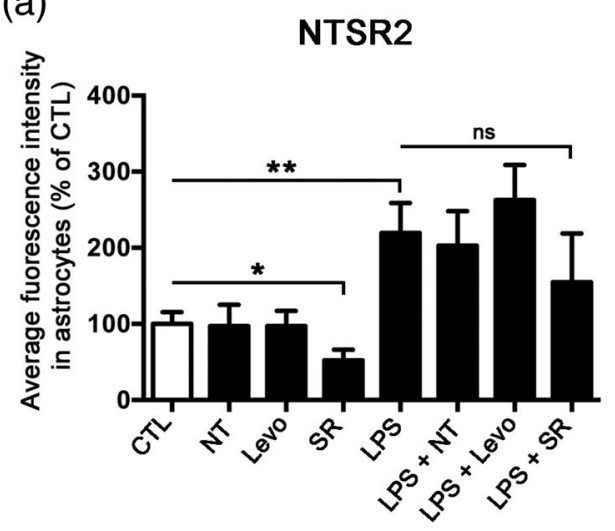

\section{Astrocytes}

(b)

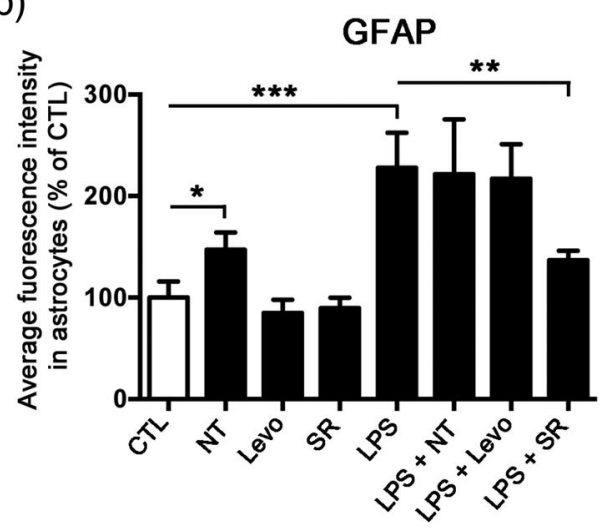

\section{Microglia}

(c)

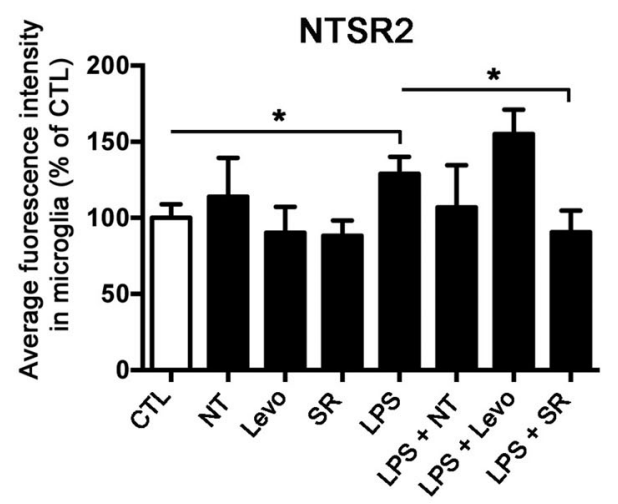

(d)

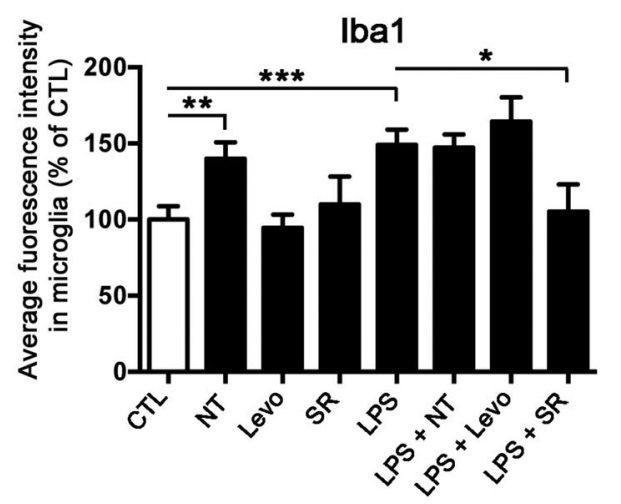

FIGURE 8 Antagonizing NTSR2 downregulates NTSR2, GFAP, and lba1 in inflamed rat primary glial cultures. Histograms comparing the average fluorescence intensity of NTSR2 (a) and GFAP (b) in astrocytes, or NTSR2 (c) and lba1 (d) in microglia. Cells were treated with neurotensin (NT), Levocabastine (Levo, NTSR2 agonist), SR142948A (SR, NTSR2 antagonist), LPS, LPS + NT, LPS + Levo, or LPS + SR at $1 \mu$ M final concentration for all molecules except LPS at $1 \mu \mathrm{g} / \mathrm{ml}$. In all cases, protein levels of NTSR2, GFAP, and lba1 all increased significantly after $24 \mathrm{~h}$ LPS alone treatment. In GFAP ${ }^{+}$astrocytes, SR alone decreased NTSR2 protein compared with untreated cells (a). NT alone increased GFAP protein compared with CTL (b). After $24 \mathrm{~h}$-LPS-treatment, SR decreased GFAP protein back to CTL levels compared with LPS alone-treated cells (b). In Iba1 ${ }^{+}$microglia (c), after $24 \mathrm{~h}$ LPS treatment, SR decreased NTSR2 protein back to CTL levels. NT alone increased lba1 protein compared with CTL (d). After 24 h-LPS-treatment, SR decreased lba1 protein back to CTL levels compared with LPS alone-treated cells (d). Values are given as the mean percentage \pm SEM normalized to CTL. Asterisks indicate statistically significant differences: ${ }^{*} p<.05,{ }^{* *} p<.01,{ }^{* * *} p<.001$ (Student's t-test) 


\section{9 | Inflammation modulates differentially the expression of NTSRs in rat primary glial cultures}

We first performed NTSR2 (Figure 6(b), green) and GFAP (Figure 6(c), red) double immunofluorescence labeling on primary glial cultures to validate our findings regarding NTSR2 astrocytic expression in rat brain tissue. Confocal microscopy analysis confirmed that all GFAPlabeled astrocytes were co-labeled for NTSR2 within the cytoplasm as well as at the cell membrane and processes (Figure 6(b,d), see arrowheads). The strong NTSR2 immunostaining observed in the cell body likely corresponds to the Golgi apparatus. We observed that not only astrocytes but the totality of cells in these glial cultures, that include astrocytes and microglial cells, were NTSR2-labeled. We performed NTSR2 (Figure 6(f), green) and Iba1 (Figure 6(g), red) double immunofluorescence on the same cultures and observed that in vitro, NTSR2 was expressed in microglial cells from primary glial cultures, in contrast to our in vivo findings. NTSR2 immunolabeling was more intense within the cell body and membrane compared with the cell processes (Figure 6(f,h)). NTSR2 expression in microglia was stronger than that observed in astrocytes of CTL glial cultures. Indeed, quantitative analysis showed that the average fluorescence intensity for NTSR2 was significantly higher in Iba1-labeled microglia (149.4 $\pm 19.7 \%, 49 \%$; $p<.05$, Student's $t$-test), compared with that of GFAP-labeled astrocytes (100 $\pm 13 \%$ ) (Figure 6(i)).

In order to study the effects of inflammation on the regulation of NTSR2 expression in primary glial cultures, cells were treated with IL1 $\beta$ and LPS. IL1 $\beta$ was chosen considering that it is induced at high levels in our model and is known to be strongly induced during the inflammatory phase in vivo, notably in epilepsy (De Simoni et al., 2000; reviewed in Fabene et al., 2010; Vezzani \& Granata, 2005; Vezzani et al., 2008; Vezzani et al., 2011). LPS was used as an additional well characterized pro-inflammatory factor shown to induce neuroinflammation and notably GFAP in vitro and in vivo (Brahmachari et al., 2006; Hauss-Wegrzyniak et al., 1998, 2000; Rosi et al., 2006; Sbai et al., 2010). The inflammatory response of primary glial cultures to IL1 $\beta$ or LPS was monitored by following the expression of IL1 $\beta$ and MCP-1/ccl2 mRNA by RT-qPCR at different time points (1, 6 , and $24 \mathrm{~h}$ ), and synthesis of MCP-1/CCL2 by ELISA after $24 \mathrm{~h}$ treatment. In contrast to IL1 $\beta$, LPS significantly induced IL1 $\beta$ mRNA levels at $1 \mathrm{~h}(8.6 \pm 2.5, n=8 ; p<.05)$ and $6 \mathrm{~h}(11.5 \pm 2.3$ $n=8 ; p<.01)$ compared with CTL $(1 \pm 0.0 ; n=8$; Tukey's test) (Figure $7(\mathrm{a})$ ). The expression of MCP-1/ccl2 mRNA levels was significantly induced by IL1 $\beta$ as well as by LPS at $6 \mathrm{~h}$ (IL1 $\beta 6 \mathrm{~h}$ : $4.1 \pm 1 ; n=8$; $p<.05$; LPS 6 h: $8.2 \pm 1 ; n=8 ; p<.001$, Tukey's test) (Figure 7(b)). Consistent with the RT-qPCR data, MCP-1/CCl2 was produced at significant levels in the supernatants of cultured glial cells after $24 \mathrm{~h}$ treatment by IL1 $\beta(357.9 \pm 25.4 \mathrm{ng} / \mathrm{ml} ; 545.5 \%)$ or LPS (716 $\pm 27.4 \mathrm{ng} / \mathrm{ml}$; 1091.3\%) as compared with CTL $(65.6 \pm 14.1 \mathrm{ng} / \mathrm{ml}$ $100 \% ; n=8 ; p<.01$; Tukey's test) (Figure 7(c)). These data confirmed that our glial cultures were inflamed. We next analyzed the expression of NTSR2 and the other NTSRs, after 1, 6, and $24 \mathrm{~h}$ treatment with either IL1 $\beta$ or LPS. Inflammation induced rapid upregulation of mRNAs encoding NTSR2 (IL1 $\beta 1$ h: $2.9 \pm 0.7 ; n=8 ; p<.05$; Tukey's test; LPS
1 h: $3.4 \pm 0.9 ; n=8 ; p<.01$; Tukey's test) (Figure 7(d)) and to a lower extent Sort1/NTSR3 (IL1 $\beta 1$ h: $1.4 \pm 0.2 ; n=8 ; p<.05$; Tukey's test; LPS $1 \mathrm{~h}: 1.6 \pm 0.2 ; n=8 ; p<.001$; Tukey's test) (Figure 7(d,e)) at $1 \mathrm{~h}$ after IL1 $\beta$ or LPS treatments. No significant modulation of NTSR2 (IL1 $\beta 6$ h: $1.4 \pm 0.5 ; n=8 ; p>.05 ;$ ANOVA; LPS 6 h: $2.1 \pm 0.4 ; n=8$; $p>.05 ;$ ANOVA) and Sort1/NTSR3 mRNA (IL1 $\beta 6 \mathrm{~h}: 1 \pm 0.1 ; p>.05$; ANOVA; LPS 6 h: $0.8 \pm 0.1 ; n=8 ; p>.05$; ANOVA) was observed after either IL1 $\beta$ or LPS treatment at $6 \mathrm{~h}$ (Figure 7(d,e)). However, significant decrease of mRNA encoding Sort1/NTSR3 was observed at $24 \mathrm{~h}$ after IL1 $\beta$ or LPS treatments (IL1 $\beta 24 \mathrm{~h}: 0.6 \pm 0.1 ; n=8$; $p<.05$; Tukey's test; LPS $24 \mathrm{~h}: 0.5 \pm 0.1 ; n=8 ; p<.01$; Tukey's test) (Figure 7(e)). Our RT-qPCR results indicated that NTSR1 mRNAs were expressed at very low levels compared with NTSR2 or Sort1/ NTSR3 ( 2000 times less based on Ct differences), and our study showed no significant modulation of NTSR1 mRNA by IL1 $\beta$ and LPS at all time points examined ( $n=8 ; p>.05$; ANOVA) (Figure $7(f)$ ). These results indicate that inflammation differentially affects the expression of NTSRs in primary glial cultures.

\subsection{0 | NTSR2 antagonism regulates NTSR2, GFAP, and Iba1 protein expression in rat primary glial cultures}

Since NTSR2 expression is regulated by inflammation, we investigated whether modulating NTSR activity with previously described agonists or antagonists could in turn regulate NTSR2 expression and glial cell inflammation. We used Levocabastine (Levo, NTSR2 agonist) (Coppola et al., 2008; Mazella et al., 1996; Richard et al., 2001), and SR142948A (SR, NTSR2 antagonist) (Gully et al., 1997; Kreitel et al., 2002; Schaeffer et al., 1998). Dual NTSR2/GFAP (Figure 8(a,b)), and NTSR2/lba1 (Figure 8(c,d)) immunocytochemistry was carried out on primary glial cultures treated with NT, Levo, SR, LPS, LPS + NT, LPS + Levo, or LPS + SR for $24 \mathrm{~h}$. The levels of fluorescence intensity of each marker were compared with those of untreated CTL astrocytes or microglia, as well as between them (Figure 8). LPS was applied at $1 \mu \mathrm{g} / \mathrm{ml}$. All ligands were applied at $1 \mu \mathrm{M}$ based on previously published results (Vincent, 1995; Vita et al., 1998). In astrocytes, quantitative analysis showed that the NTSR2 antagonist SR142948A significantly reduced NTSR2 protein expression $(52.3 \pm 14 ; 48 \%$; $n=3$ in duplicate; $p=.02$; Student's $t$-test) compared with untreated CTL cultures (Figure 8(a)). LPS caused significant increase of NTSR2 protein expression (219.4 $\pm 39.6 ; 119 \% ; n=3$ in duplicate; $p=.005$; Student's $t$-test) compared with CTL. SR decreased NTSR2 protein levels in LPS-inflamed astrocytes but did not reach the level of significance $(154.8 \pm 64)$. NT alone significantly increased GFAP protein expression (147.2 $\pm 17 ; 47 \% ; n=3$ in duplicate; $p=.042$; Student's $t$ test) compared with CTL astrocytes $(100 \pm 15.9)$ (Figure 8(b)), suggesting that treatment with a NTSR2 agonist increased astrocytic inflammation. GFAP levels, similarly to NTSR2, were also increased significantly after $24 \mathrm{~h}$ LPS treatment $(227.9 \pm 34.5 ; 128 \% ; n=3$ in duplicate; $p=.0008$; Student's $t$-test) when compared with CTL astrocytes. GFAP protein was significantly downregulated upon SR 
treatment in LPS-treated astrocytes (136.6 \pm 9.2; 91\%; $n=3$ in duplicate; $p=.01$; Student's $t$-test) compared with LPS alone. These data indicated that antagonizing NTSR2 may regulate astrocytic inflammation.

Considering that NTSR2 is expressed also in microglial cells in vitro, the levels of NTSR2 and Iba1 were also quantified in double labeled cells and compared in the same glial cultures treated under the same conditions. As for astrocytes, LPS led to a significant increase of NTSR2 protein expression $(128.7 \pm 11.2 ; 29 \%$; $n=3$ in duplicate; $p=.045$; Student's $t$-test) as compared with CTL. Cultures treated simultaneously with LPS and SR led to significantly decreased NTSR2 levels compared with LPS-treated cells alone (90.5 \pm 14.3 ; $38 \% ; n=3$ in duplicate; $p=.03$; Student's $t$-test) (Figure 8(c)). Similarly to astrocytes, NT treatment in primary glial cultures led to significant increase of lba1 levels in microglial cells (139.8 $\pm 10.7 ; 40 \%$; $n=3$ in duplicate; $p=.004$; Student's $t$-test) as compared with CTL $(100 \pm 8.8$ ) (Figure 8(d)). Also, similarly to GFAP and NTSR2 levels both in astrocytes and microglia, Iba1 protein expression was significantly increased after $24 \mathrm{~h}$ treatment with LPS (149.1 $\pm 10 ; 49 \%$; $n=3$ in duplicate; $p=.0002$; Student's $t$-test), compared with CTL. Finally, SR significantly decreased Iba1 protein expression in LPSinflamed microglia compared with LPS-treated microglia alone (105.3 $\pm 17.7 ; 44 \% ; n=3$ in duplicate; $p=.032$; Student's $t$-test), suggesting that blocking NTSR2 can potentially modulate microglial inflammation. Collectively, these results showed that at least in vitro, NTSR2 is induced at high levels in both reactive astrocytes and microglia, and that astrocyte and microglial reactivity can be modulated by a NTSR2 agonist (NT) and antagonist (SR).

\subsection{NTSR2 is expressed as an immediate early gene in inflamed rat glial cultures}

The transient and rapid (as early as $1 \mathrm{~h}$ ) upregulation by inflammation of mRNAs encoding NTSR2 and Sort1/NTSR3 was reminiscent of the pattern of expression of immediate-early genes (IEGs). Expression of such primary response genes is independent of protein synthesis (Alberini, 2008; Herschman, 1991; Lau \& Nathans, 1991). In order to determine whether the activation of NTSR2 and Sort1/NTSR3 requires protein synthesis, we incubated glial cells with or without LPS $(1 \mu \mathrm{g} / \mathrm{ml})$ and/or cycloheximide $(\mathrm{CHX})$, a protein synthesis inhibitor at $10 \mu \mathrm{g} / \mathrm{ml}$ (Cochran et al., 1984; Greenfield et al., 1996), for 1, 6, and $24 \mathrm{~h}$ prior to RNA extraction and RT-qPCR analysis. We used as a standard positive control Zif-268/egr-1, a zinc-finger protein known to be rapidly induced in diverse cell types following activation by a variety of stimulants, including LPS (Gashler \& Sukhatme, 1995; Xu et al., 2001; Yao et al., 1997). RT-qPCR analysis demonstrated that in rat glial cells, LPS alone induced strong, rapid and transient expression of Zif-268/egr-1 mRNA, with a peak in mRNA levels occurring at the $1 \mathrm{~h}$ time point ( $23 \pm 0.5$; 23-fold; $n=3 ; p<.001$; Tukey's test) as compared with untreated CTL cells $(1 \pm 0.0)$ (Figure S9(a)). When combining LPS with $\mathrm{CHX}$ in glial cell cultures, we observed a superinduction of Zif-268/egr-1 mRNA at all time points compared with
LPS (Figure S9(a), left plot) with a 7.7-fold super-induction of Zif-268/ egr-1 mRNA levels at $1 \mathrm{~h}(177.1 \pm 15.3 ; n=3 ; p<.05$; Tukey's t-test) over LPS alone (Figure S9(a), right diagram). Thus, the zif-268/egr-1 gene is induced as an IEG by LPS in rat primary glial cells and this induction is independent of de novo protein synthesis, consistent with other cell types (Gashler \& Sukhatme, 1995; Hughes et al., 1993; Xu et al., 2001; Yamaji et al., 1994; Yao et al., 1997).

LPS alone induced rapid and transient expression of NTSR2 and Sort1/NTSR3 (Figure S9(b,c), left plots), with mRNA expression peaking at the $1 \mathrm{~h}$ time point (NTSR2: $3.7 \pm 0.3$; Sort1/NTSR3: 2.8 $\pm 0.2 ; n=3 ; p<.001$; Tukey's test) when compared with untreated CTL glial cells ( $1 \pm 0.0$ ) (Figure S9(b,c), right diagrams). CHX-treatment alone also induced NTSR2 (3.9 $\pm 0.3 ; 6$ h: $3 \pm 0.2$; 3-fold; 24 h: 3.4 \pm 0.2; 3.4-fold; $n=3 ; p<.001$; Tukey's t-test) and Sort1/NTSR3 (1 h: $3.1 \pm 0.2 ; 3.1$-fold; 6 h: $2.2 \pm 0.1 ; 2.2$-fold; 24 h: $2.1 \pm 0.0 ; 2.1$-fold; $n=3 ; p<.001$; Tukey's test) mRNA levels at all time points compared with CTL (Figure S9 $(\mathrm{a}-\mathrm{c})$ ). CHX treatment did not block activation of NTSR2 and Sort1/NTSR3, similarly to our results with Zif-268/egr-1, indicating that LPS induction of NTSR2 and Sort1/NTSR3 mRNA levels were not dependent upon de novo protein synthesis. Taken together with the rapid and transient kinetics of activation, our results suggested that Ntsr2 and Sort1/Ntsr3 genes respond as IEGs in cultured rat glial cells.

\section{4 | DISCUSSION}

Our study shows that NTSR2 protein is expressed in rodent hippocampal astrocytes and increases together with astrocyte reactivity in the early phases following induction of SE in two models of TLE. Following SE, NTSR2 immunoreactivity was also increased in perivascular astrocytes and their end-feet and was apparent in endothelial cells. Proinflammatory stimulation mediated by IL1 $\beta$ or LPS induced NTSR2 in astroglia in vitro. Treating cultured glial cells with a NTSR2 antagonist decreased NTSR2, GFAP, and lba1 expression. Together, our results suggest a role for NTSR2 in the regulation of gliovascular inflammation.

\subsection{NTSR2 protein is expressed in astrocytes in rat brain}

In the present work, we investigated in vivo and in vitro, by immunohisto-chemistry and immunocyto-chemistry laser scanning confocal microscopy approaches, the expression of the NTSR2 protein in rat hippocampal cells using GFAP labeling combined with a specific and validated anti-NTSR2 antibody. Our study clearly demonstrates that the NTSR2 protein is expressed in the DG and CA1-CA3 regions of Ammon's horn.

Recently, NTSR2 was shown to be expressed in the DG and CA3 in a transgenic mice line (NtsR2 ${ }^{\mathrm{Cre} /+, \mathrm{GFP}}$ ), however the identity of the non-neuronal (NeuN-negative) NTSR2-expressing cells was not revealed (Manning et al., 2019). In our study, we also observed 
differential NTSR2 expression in hippocampal neurons (Kyriatzis et al., in preparation) but in the present report we chose to focus our attention on the non-neuronal expression of the NTSR2 protein. We show NTSR2 protein expression in all GFAP-labeled astrocytes. A high throughput study showed that NTSR2 mRNA is one of the most abundant receptor-encoding mRNAs in purified mice astrocytes (Zhang et al., 2014), and in vitro, NTSR2 has been used as an astrocytic marker in single-cell transcriptomic analysis (Dulken et al., 2017). RT-qPCR assays showed that cultured astroglial cells express NTSR2 mRNA and its isoform (vNTSR2) rather than NTSR1 (our present data; Ayala-Sarmiento et al., 2015). In situ hybridization (ISH) studies in vivo showed NTSR2 mRNA expression in rat astrocytes (Walker et al., 1998; Yamauchi et al., 2007), and in astrocytes of P17 mice (Cahoy et al., 2008). Dual immunohistochemical labeling of GFAP and ISH of NTSR2 mRNA suggested that NTSR2 was expressed in only a small subset of astrocytes in the rat brain (Nouel et al., 1999). ISH localized NTSR2 mRNA in a subpopulation of astrocytes of the median preoptic nucleus (Tabarean, 2020). At the protein level, previous studies based on NT-binding experiments and sensitivity to Levocabastine, a NTSR2 ligand that does not bind to NTSR1 or Sort1/ NTSR3, suggested NTSR2 protein expression in cultured astrocytes. Bound fluorescent NT indicated that receptor expression concerned only a sub-population of astrocytes in culture (Sarret \& Beaudet, 2002). NTSR2 immunostaining was reported in astrocytes of the ventral tegmental area (Woodworth et al., 2018). However, another study based on double-immunolabeling combining an N-terminal-specific anti-NTSR2 antibody and the astrocyte marker calciumbinding protein $S 100 \beta$, reported absence of NTSR2 immunostaining in adult rat brain astrocytes (Sarret et al., 2003).

With regard to subcellular localization, we observed in vivo and in vitro, that NTSR2 is localized at the glial cell membrane, typical for a receptor; however we also observed NTSR2 aggregates in astrocytic processes and cell bodies, reminiscent of NTSR2 localization in intracellular vesicles and in the trans-Golgi network described in rat spinal cord neurons (Perron et al., 2006).

\subsection{NTSR2 is induced in reactive astrocytes in rodent models of epilepsy}

We questioned whether astrocytic NTSR2 expression was modulated in pathological situations involving astrocyte reactivity. To address this issue, we studied two pathophysiological models of TLE induced by pilocarpine in rats and KA in mice. NTSR2 expression was largely increased both after pilocarpine-induced and KA-induced SE in all hippocampal areas. The NTSR2 increase following SE coincides with the peak of astrocyte activation and prolonged elevation of astrocytic $\mathrm{Ca}^{2}$ ${ }^{+}$signaling, which occurs at 3 days post-SE in different rodent experimental models (Seifert et al., 2010). These reactive astrocytes were shown to contribute to delayed neuronal death of cortical and hippocampal pyramidal cells following pilocarpine-induced SE (Ding et al., 2007). Accordingly, at 3 months post-SE, characterized by spontaneous recurrent seizures and attenuated astrocytic reactivity
(Choi \& Koh, 2008; Garzillo \& Mello, 2002), we observed concomitant decrease of NTSR2. The fact that the NTSR2 expression pattern closely follows that of astrocyte reactivity during the course of the disease, provides a hint that this receptor is involved in the neuroinflammation processes associated with pathology. Reactive gliosis can be heterogeneous in response to specific injury. For instance, the molecular phenotypes of reactive astrocytes induced by ischemia and LPS suggest that they may be beneficial or detrimental, respectively (Zamanian et al., 2012). In other neuroinflammatory settings, such as those induced by brain stab-wound in rats, a marked increase in the number of NTSR2 mRNA expressing astrocytes around the lesion has been described, associated with increased NTSR2 mRNA expression at the cellular level (Nouel et al., 1999). Taken together these results suggest that NTSR2 upregulation during astrocytic reactivity may be common to different brain injuries and different species.

\section{3 | NTSR2 is induced in reactive astrocytes and microglial cells in vitro following proinflammatory stimulation}

We showed that PILO rats displayed increased expression of major inflammatory cytokines, as reported in different epileptic models (De Simoni et al., 2000; Vieira et al., 2014; Voutsinos-Porche et al., 2004). Among cytokines, IL1 $\beta$ appeared to be the most induced in vivo, in the same cell types and structures as those observed for NTSR2 induction. Thus, IL1 $\beta$ was used, in parallel with LPS, to study the effects of neuroinflammation on the regulation of NTSR2 in astroglial cultures. A major finding of our study is that inflammation mediated by these factors significantly enhanced NTSR2 mRNA or protein levels in these cultures, congruent with our in vivo data. We show NTSR2 mRNA upregulation following IL1 $\beta$ and NTSR2 protein upregulation after LPS-mediated inflammation in glial cells, and results are in agreement with Pang et al. (2001), who reported increased expression of NTSR2 mRNA in astrocytes following LPS stimulation. In the adult rat and mouse hippocampus, in both the PILO and KA models, we observed strong lba1 immunolabeling, indicative of microglial reactivity. However, we showed that NTSR2 was expressed specifically in astrocytes and not in CTL or reactive microglia, that also contribute to inflammation associated with epilepsy. It is acknowledged that primary glial cultures are in vitro models that do not fully mimic the complex events occurring in vivo. Nevertheless, these cultures remain invaluable tools to study physiological and pathological states and have led to major discoveries in glial function (reviewed in Streit, 2010; Lange et al., 2012). The in vivo and in vitro discrepancy could result from differential behavior of microglial cells in in vivo and in vitro conditions, and/or distinct microglia responses to the proinflammatory factors expressed in vivo and those we assessed in vitro. We cannot exclude that microglial cell-induction of NTSR2 could occur in vivo in other models of pathology-induced neuroinflammation. To our knowledge, this is the first demonstration of NTSR2 expression in microglia, as previous studies reported that cultured murine and 
human microglia cells express only Sort1/NTSR3 but not NTSR1 nor NTSR2 (Martin et al., 2003; Patel et al., 2016).

\subsection{Astrocyte and microglial reactivity are increased by NT and decreased by the NTSR 2 antagonist SR142948A}

In vitro, we found that inflammation regulated NTSR2, GFAP, and Iba1 protein expression. NTSR2 stimulation with its principal agonist NT led to increased GFAP and Iba1 protein expression in CTL astrocytes and microglia. Conversely, the NTSR2 antagonist SR142948A decreased GFAP, Iba1, and NTSR2 expression in CTL or inflamed astrocytes and microglia, suggesting that blocking NTSR2 attenuates astrocytic and microglial reactivity. It has been shown that activation of NTSR2 by its ligand can result in modulation of gene expression (Ayala-Sarmiento et al., 2015; Gendron et al., 2004; Vita et al., 1998). Consistent with our data, inhibition of NTSR2 by JMV449, a general NTSR antagonist, suppressed GFAP expression, potentially by affecting transcriptional 3 (STAT3) factor signaling (Ando et al., 2019).

Different NTSR2 ligands behave as agonists or antagonists, depending on specific signaling events and the cell types studied (Dobner, 2005; Mazella et al., 1996, 1998; Richard et al., 2001) SR142948A is a potent antagonist of both NTSR1 and NTSR2 (Dobner, 2005; Gully et al., 1997; Vita et al., 1998). Levocabastine acts as a NTSR2 agonist in mammals and amphibians (Coppola et al., 2008; Dong et al., 2015; Hwang et al., 2009; Sarret et al., 2002). In any case, NT and SR142948A display opposing effects in different cell systems. In Chinese hamster ovarian (CHO) cells transfected with human NTSR2, SR142948A triggered responses that were inhibited by NT and Levocabastine (Vita et al., 1998). SR142948A inactivated NTSR2 and restored apoptosis in leukemic B cells that exhibit high NTSR2 and low NTSR1 expression (Abbaci et al., 2018). We hypothesize that GFAP, Iba1 and NTSR2 expression modulated by SR142948A, involves NTSR2 considering that there is no NTSR1 function in glial cells (Nouel et al., 1999) and that this receptor appears expressed at very low levels in these cells.

$G$ protein coupled receptors (GPCRs) have been shown to play important roles in inflammation and their involvement in transmembrane signaling is primarily responsible for the mediation of complex inflammatory (and anti-inflammatory) responses (reviewed in Sun \& Ye, 2012). As such, NTSRs and the neurotensinergic system have been involved in various inflammatory disease states. NT has been shown to promote an acute inflammatory response in an experimental model of colon inflammation (Castagliuolo et al., 1999). In contrast, an ameliorative effect of NT in the colitis model of inflammatory bowel disease has been reported, that reduces the levels of the proinflammatory cytokines IL6 and tumor necrosis factor $\alpha$ (TNF $\alpha$ ) that are highly expressed in this model (Akcan et al., 2008). Also, NT reduced apoptosis in pancreatic cells treated with IL1 $\beta$ and this beneficial effect was mediated by NTSR2 (Coppola et al., 2008). In the latter case, NT acted as antagonist of NTSR2, leading to its downregulation and reduction of inflammation.

With regard to brain diseases, NT has been studied in schizophrenia, Alzheimer's disease, and Parkinson's disease among others (reviewed in St-Gelais et al., 2006). However, the specific role of NT in neuroinflammation in these disorders has not been addressed, nor which receptors are involved.

\subsection{NTSR2 is expressed as immediate early gene in inflamed glial cells}

The transient and rapid upregulation of NTSR2 and Sort1/NTSR3 mRNA after treatment with proinflammatory agents such as LPS and IL1 $\beta$ led us to question whether these NTSRs could be categorized as IEGs. These are characterized by rapid-in general within an hourand transient upregulation in response to different cell stimuli. In addition, this upregulation should be independent of de novo protein synthesis (Bahrami \& Drabløs, 2016; Fowler et al., 2011; Mehendale \& Apte, 2009). Our results show that the NTSR2 and Sort1/NTSR3 mRNA expression levels that were increased as early as $1 \mathrm{~h}$ after LPS were unaltered by $\mathrm{CHX}$. In line with our data, several studies revealed that the NR4A subfamily of nuclear receptors responds to inflammation (Martinez-Gonzalez \& Badimon, 2005; Maxwell \& Muscat, 2006), similar to NTSR2 and Sort1/NTSR3. Several IEGs have been shown to play important roles in transmitting the activation signal downstream via transcription factors to dictate expression patterns of particular target genes with immunological significance. It is the case for example for Zif-268/egr-1 shown to play a role in immune responses by regulating downstream gene targets encoding interleukin-2, CD44, ICAM-1, TNF, and NR4A1 in immune cells (Bahrami \& Drabløs, 2016; Martinez-Gonzalez \& Badimon, 2005; McMahon \& Monroe, 1996). It is appealing to suggest that Zif-268/egr-1 may play a role in triggering immune responses in activated glial cells leading to the expression of NTSR2, Sort1/NTSR3, and immune response factors we describe in glial cells such as GFAP, MCP1/ccl2, and Iba1.

\subsection{NTSR2 is expressed in blood vessel endothelial cells and increased in rodent models of epilepsy}

Besides NTSR2 expression in hippocampal astrocytes, we observed perivascular NTSR2 and GFAP labeling that was enhanced following SE. In epileptic animals, confocal analysis of GFAP and NTSR2 double labeling immunohistochemistry showed some NTSR2 and GFAP colocalization in astrocytic end-feet. These are polarized around the basement membrane, where they maintain the structural integrity of the BBB and restrict vascular permeability (Abbott et al., 2006). In addition, blood vessels were surrounded by a large number of reactive hypertrophic astrocytes known to be associated with neuroinflammatory and neurodegenerative diseases (Hol \& Pekny, 2015).

A number of molecules have been identified whose expression is increased in reactive astrocytes as well as in their perivascular processes. For instance, aquaporin-4 (AQP-4) that mediates the delivery of nutrients to surrounding neurons is increased in sclerotic hippocampi from patients with TLE and correlates positively with increased 
GFAP in the astrocyte plasma membranes, but also in perivascular end-feet (Binder et al., 2012; Lee et al., 2004).

One major finding of our study is that NTSR2 is not exclusively co-localized with GFAP but is also found distributed between astrocytic end-feet and blood vessel lumen. Triple immunolabeling experiments to localize NTSR2, CD31, PDGFR $\beta$, and CollV showed that NTSR2 was expressed in brain endothelial cells, and only faintly in pericytes in epileptic animals. Co-upregulation of specific proteins in both astrocytes and endothelial cells in disease or inflammation has been reported. For instance, IL1 $\beta$ upregulates GLUT1 both in astrocytes and endothelial cells (Jurcovicova, 2014). Similarly, Lcn2, a secreted lipophilic protein was strongly induced after LPS injury, not only in reactive astrocytes but also in endothelial cells (Zamanian et al., 2012). Taken together, our results indicated that NTSR2 was expressed by different components of the blood vessels, in particular perivascular astrocytes and endothelial cells in epileptic animals and may be implicated in the structural integrity of the BBB. While human pulmonary artery endothelial cells (PAECs) were shown to express Sort1/NTSR3 (Shults et al., 2018), to our knowledge, our study is the first to show NTSR2 expression in blood vessels in general and in the BBB in particular. This finding suggests that while NTSR2 induction is associated with neuroinflammation involving astrocyte reactivity, it may also play a specific role in brain endothelial cells. For instance, NTSR2 could be involved in modulating endothelial cel properties due to its function as a signal transduction receptor (Martin et al., 2003; Navarro et al., 2006; Sarret et al., 2002). Interestingly, it has been shown that NTSR2 is internalized after NT binding and that receptor internalization is prevented by Levocabastine (Ayala-Sarmiento et al., 2015; Nouel et al., 1999). Finally, it has also been shown that the mouse NTSR2 recycles to the cell membrane (Martin et al., 2002). Nothing is known at this stage for NTSR2 internalization and recycling in brain endothelial cells. However, this receptor could be involved in NT endocytosis, intracellular release of NT and recycling at the cell membrane, meeting the conditions for transcytosis of NT and its stable analogs (Boules et al., 2006; Kokko et al., 2005) across the BBB if these functional properties were confirmed in brain endothelial cells.

\section{5 | CONCLUSION}

In all, our work demonstrates the involvement of the neurotensinergic system in glia and glio-vascular unit in conditions of neurological diseases. Our results show that NTSR2 is implicated in astroglial and perivascular inflammation and its expression is induced following inflammation by pro-inflammatory factors. A NTSR2 antagonist downregulates glial inflammation suggesting that NTSR2 may regulate glial responses to injury and that targeting the NTSR2 receptor may open new avenues in the regulation of neuroinflammation.

\section{ACKNOWLEDGMENTS}

This work was supported by a fellowship to GK from the European Union's Horizon 2020 research and innovation program under the
Marie Sklodowska-Curie grant agreement No 642881, and AMIDEX (ICN PhD Program, ANR-11-IDEX-0001-02 grant) funded by the French Government "Investissements d'Avenir" program. Funding from the CNRS and Aix-Marseille Université (AMU) to the Institute of Neurophysiopathology (INP), UMR7051 is acknowledged. We are grateful to Antoine Ghestem for help on the rat pilocarpine model and Dr. Jean-Pierre Kessler and Dr. Fabien Tell for helpful discussions and sharing lab space and equipment. We also thank Stéphane Girard, Christophe Fraisier, and Yasmine Mechioukhi (all from Vect-Horus SAS, Marseille) for providing PDGFR $\beta$, CD31 and CollV antibodies. Last, we thank Dr. Mourad Mekaouche and Axel Fernandez for advice and help with animal care, as well as Yves Gobin for laboratory assistance.

\section{CONFLICT OF INTEREST}

The authors declare no conflicts of interest.

\section{DATA AVAILABILITY STATEMENT}

The data that support the findings of this study are available from the corresponding author upon reasonable request.

\section{ORCID}

Lotfi Ferhat (D) https://orcid.org/0000-0003-2763-9472

Michel Khrestchatisky (D) https://orcid.org/0000-0003-4797-8332

\section{REFERENCES}

Abbaci, A., Talbot, H., Saada, S., Gachard, N., Abraham, J., Jaccard, A., Bordessoule, D., Fauchais, A. L., Naves, T., \& Jauberteau, M. O. (2018). Neurotensin receptor type 2 protects B-cell chronic lymphocytic leukemia cells from apoptosis. Oncogene, 37(6), 756-767. https://doi. org/10.1038/onc.2017.365

Abbott, N. J., Rönnbäck, L., \& Hansson, E. (2006). Astrocyte-endothelial interactions at the blood-brain barrier. Nature Reviews. Neuroscience, 7 (1), 41-53. https://doi.org/10.1038/nrn1824

Akcan, A., Muhtaroglu, S., Akgun, H., Akyildiz, H., Kucuk, C., Sozuer, E., Yurci, A., \& Yilmaz, N. (2008). Ameliorative effects of bombesin and neurotensin on trinitrobenzene sulphonic acid-induced colitis, oxidative damage and apoptosis in rats. World Journal of Gastroenterology, 14(8), 1222-1230. https://doi.org/10.3748/wjg.14.1222

Alberini, C. M. (2008). The role of protein synthesis during the labile phases of memory: Revisiting the skepticism. Neurobiology of Learning and Memory, 89(3), 234-246. https://doi.org/10.1016/j.nlm.2007. 08.007

Ando, T., Kato, R., \& Honda, H. (2019). Identification of an early cell fate regulator by detecting dynamics in transcriptional heterogeneity and co-regulation during astrocyte differentiation. NPJ Systems Biology and Applications, 5, 18. https://doi.org/10.1038/s41540-019-0095-2

Armulik, A., Genové, G., \& Betsholtz, C. (2011). Pericytes: Developmental, physiological, and pathological perspectives, problems, and promises. Developmental Cell, 21(2), 193-215. https://doi.org/10.1016/j.devcel. 2011.07.001

Ayala-Sarmiento, A. E., Martinez-Fong, D., \& Segovia, J. (2015). The internalization of neurotensin by the low-affinity neurotensin receptors (NTSR2 and vNTSR2) activates ERK $1 / 2$ in glioma cells and allows neurotensin-polyplex transfection of tGAS1. Cellular and Molecular Neurobiology, 35(6), 785-795. https://doi.org/10.1007/s10571-0150172-z

Baghirova, S., Hughes, B. G., Hendzel, M. J., \& Schulz, R. (2015). Sequential fractionation and isolation of subcellular proteins from tissue or 
cultured cells. MethodsX, 2, 440-445. https://doi.org/10.1016/j.mex. 2015.11.001

Bahrami, S., \& Drabløs, F. (2016). Gene regulation in the immediate-early response process. Advances in Biological Regulation, 62, 37-49. https:// doi.org/10.1016/j.jbior.2016.05.001

Béraud-Dufour, S., Coppola, T., Massa, F., \& Mazella, J. (2009). Neurotensin receptor-2 and -3 are crucial for the anti-apoptotic effect of neurotensin on pancreatic beta-TC3 cells. The International Journal of Biochemistry \& Cell Biology, 41(12), 2398-2402. https://doi.org/10. 1016/j.biocel.2009.04.002

Binder, D. K., Nagelhus, E. A., \& Ottersen, O. P. (2012). Aquaporin-4 and epilepsy. Glia, 60(8), 1203-1214. https://doi.org/10.1002/glia.22317

Boulland, J.-L., Ferhat, L., Tallak Solbu, T., Ferrand, N., Chaudhry, F. A. Storm-Mathisen, J., \& Esclapez, M. (2007). Changes in vesicular transporters for gamma- aminobutyric acid and glutamate reveal vulnerability and reorganization of hippocampal neurons following pilocarpineinduced seizures. The Journal of Comparative Neurology, 503, 466-485. https://doi.org/10.1002/cne.21384

Boules, M., Fredrickson, P., \& Richelson, E. (2006). Bioactive analogs of neurotensin: Focus on CNS effects. Peptides, 27(10), 2523-2533. https://doi.org/10.1016/j.peptides.2005.12.018

Brahmachari, S., Fung, Y. K., \& Pahan, K. (2006). Induction of glial fibrillary acidic protein expression in astrocytes by nitric oxide. The Journal of Neuroscience: The Official Journal of the Society for Neuroscience, 26 (18), 4930-4939. https://doi.org/10.1523/JNEUROSCI.5480-05. 2006

Cahoy, J. D., Emery, B., Kaushal, A., Foo, L. C., Zamanian, J. L., Christopherson, K. S., Xing, Y., Lubischer, J. L., Krieg, P. A., Krupenko, S. A., Thompson, W. J., \& Barres, B. A. (2008). A transcriptome database for astrocytes, neurons, and oligodendrocytes: $A$ new resource for understanding brain development and function. The Journal of Neuroscience: The Official Journal of the Society for Neuroscience, 28(1), 264-278. https://doi. org/10.1523/JNEUROSCI.4178-07.2008

Castagliuolo, I., Wang, C. C., Valenick, L., Pasha, A., Nikulasson, S., Carraway, R. E., \& Pothoulakis, C. (1999). Neurotensin is a proinflammatory neuropeptide in colonic inflammation. The Journal of Clinical Investigation, 103(6), 843-849. https://doi.org/10.1172/JCl4217

Chalon, P., Vita, N., Kaghad, M., Guillemot, M., Bonnin, J., Delpech, B., Le Fur, G., Ferrara, P., \& Caput, D. (1996). Molecular cloning of a levocabastine-sensitive neurotensin binding site. FEBS Letters, 386(2-3), 91-94. https://doi.org/10.1016/0014-5793(96)00397-3

Chen, Z., Duan, R.-S., Quezada, H. C., Mix, E., Nennesmo, I., Adem, A., Winblad, B., \& Zhu, J. (2005). Increased microglial activation and astrogliosis after intranasal administration of kainic acid in C57BL/6 mice. Journal of Neurobiology, 62(2), 207-218. https://doi.org/10. 1002/neu.20099

Choi, J., \& Koh, S. (2008). Role of brain inflammation in epileptogenesis. Yonsei Medical Journal, 49(1), 1-18. https://doi.org/10.3349/ymj. 2008.49.1.1

Clifford, D. B., Olney, J. W., Maniotis, A., Collins, R. C., \& Zorumski, C. F. (1987). The functional anatomy and pathology of lithium-pilocarpine and high-dose pilocarpine seizures. Neuroscience, 23(3), 953-968. https://doi.org/10.1016/0306-4522(87)90171-0

Cochran, B. H., Zullo, J., Verma, I. M., \& Stiles, C. D. (1984). Expression of the c-fos gene and of an fos-related gene is stimulated by plateletderived growth factor. Science (New York, NY), 226(4678), 1080-1082. https://doi.org/10.1126/science.6093261

Coppola, T., Béraud-Dufour, S., Antoine, A., Vincent, J.-P., \& Mazella, J. (2008). Neurotensin protects pancreatic beta cells from apoptosis. The International Journal of Biochemistry \& Cell Biology, 40(10), 2296-2302. https://doi.org/10.1016/j.biocel.2008.03.015

Cragnolini, A. B., Huang, Y., Gokina, P., \& Friedman, W. J. (2009). Nerve growth factor attenuates proliferation of astrocytes via the $\mathrm{p} 75$ neurotrophin receptor. Glia, 57(13), 1386-1392. https://doi.org/10.1002/ glia.20857
De Simoni, M. G., Perego, C., Ravizza, T., Moneta, D., Conti, M., Marchesi, F., De Luigi, A., Garattini, S., \& Vezzani, A. (2000). Inflammatory cytokines and related genes are induced in the rat hippocampus by limbic status epilepticus. The European Journal of Neuroscience, 12(7), 2623-2633. https://doi.org/10.1046/j.1460-9568.2000. 00140.x

Devader, C., Béraud-Dufour, S., Coppola, T., \& Mazella, J. (2013). The antiapoptotic role of neurotensin. Cell, 2(1), 124-135. https://doi.org/10. 3390/cells2010124

Ding, M., Haglid, K. G., \& Hamberger, A. (2000). Quantitative immunochemistry on neuronal loss, reactive gliosis and BBB damage in cortex/striatum and hippocampus/amygdala after systemic kainic acid administration. Neurochemistry International, 36(4-5), 313-318. https://doi.org/10.1016/s0197-0186(99)00139-4

Ding, S., Fellin, T., Zhu, Y., Lee, S.-Y., Auberson, Y. P., Meaney, D. F., Coulter, D. A., Carmignoto, G., \& Haydon, P. G. (2007). Enhanced astrocytic $\mathrm{Ca} 2+$ signals contribute to neuronal excitotoxicity after status epilepticus. The Journal of Neuroscience: The Official Journal of the Society for Neuroscience, 27(40), 10674-10684. https://doi.org/10. 1523/JNEUROSCI.2001-07.2007

Dobner, P. R. (2005). Multitasking with neurotensin in the central nervous system. Cellular and Molecular Life Sciences: CMLS, 62(17), 1946-1963. https://doi.org/10.1007/s00018-005-5128-x

Dong, X., Bai, X., Zhao, J., Wang, L., Wang, Q., \& Li, L. (2015). The actions of neurotensin in rat bladder detrusor contractility. Scientific Reports, 5, 11192. https://doi.org/10.1038/srep11192

Dulken, B. W., Leeman, D. S., Boutet, S. C., Hebestreit, K., \& Brunet, A. (2017). Single cell transcriptomic analysis defines heterogeneity and transcriptional dynamics in the adult neural stem cell lineage. Cell Reports, 18(3), 777-790. https://doi.org/10.1016/j.celrep.2016. 12.060

Dusart, I., Marty, S., \& Peschanski, M. (1991). Glial changes following an excitotoxic lesion in the CNS-II Astrocytes. Neuroscience, 45(3), 541-549. https://doi.org/10.1016/0306-4522(91)90269-t

EIAli, A., Thériault, P., \& Rivest, S. (2014). The role of pericytes in neurovascular unit remodeling in brain disorders. International Journal of Molecular Sciences, 15(4), 6453-6474. https://doi.org/10.3390/ ijms15046453

Fabene, P. F., Bramanti, P., \& Constantin, G. (2010). The emerging role for chemokines in epilepsy. Journal of Neuroimmunology, 224(1), 22-27. https://doi.org/10.1016/j.jneuroim.2010.05.016

Fowler, T., Sen, R., \& Roy, A. L. (2011). Regulation of primary response genes. Molecular Cell, 44(3), 348-360. https://doi.org/10.1016/j. molcel.2011.09.014

Friry, C., Feliciangeli, S., Richard, F., Kitabgi, P., \& Rovere, C. (2002). Production of recombinant large proneurotensin/neuromedin $\mathrm{N}$-derived peptides and characterization of their binding and biological activity. Biochemical and Biophysical Research Communications, 290(4), 11611168. https://doi.org/10.1006/bbrc.2001.6308

Garzillo, C., \& Mello, L. (2002). Characterization of reactive astrocytes in the chronic phase of the pilocarpine Model of Epilepsy. Epilepsia, 43, 107-109. https://doi.org/10.1046/j.1528-1157.43.s.5.40.x

Gashler, A., \& Sukhatme, V. P. (1995). Early growth response protein 1 (Egr-1): Prototype of a zinc-finger family of transcription factors. Progress in Nucleic Acid Research and Molecular Biology, 50, 191-224. https://doi.org/10.1016/s0079-6603(08)60815-6

Gendron, L., Perron, A., Payet, M. D., Gallo-Payet, N., Sarret, P., \& Beaudet, A. (2004). Low-affinity neurotensin receptor (NTS2) signaling: Internalization-dependent activation of extracellular signalregulated kinases 1/2. Molecular Pharmacology, 66(6), 1421-1430. https://doi.org/10.1124/mol.104.002303

Green, B. R., White, K. L., McDougle, D. R., Zhang, L., Klein, B. Scholl, E. A., Pruess, T. H., White, H. S., \& Bulaj, G. (2010). Introduction of lipidization-cationization motifs affords systemically bioavailable neuropeptide $Y$ and neurotensin analogs with anticonvulsant activities. 
Journal of Peptide Science, 16(9), 486-495. https://doi.org/10.1002/ psc.1266

Greenfield, E. M., Horowitz, M. C., \& Lavish, S. A. (1996). Stimulation by parathyroid hormone of interleukin- 6 and leukemia inhibitory factor expression in osteoblasts is an immediate-early gene response induced by cAMP signal transduction. The Journal of Biological Chemistry, 271 (18), 10984-10989. https://doi.org/10.1074/jbc.271.18.10984

Gueye, Y., Ferhat, L., Sbai, O., Bianco, J., Ould-Yahoui, A., Bernard, A., Charrat, E., Chauvin, J.-P., Risso, J.-J., Féron, F., Rivera, S., \& Khrestchatisky, M. (2011). Trafficking and secretion of matrix metalloproteinase-2 in olfactory ensheathing glial cells: A role in cell migration? Glia, 59(5), 750-770. https://doi.org/10.1002/glia.21146

Gully, D., Labeeuw, B., Boigegrain, R., Oury-Donat, F., Bachy, A., Poncelet, M., Steinberg, R., Suaud-Chagny, M. F., Santucci, V., Vita, N., Pecceu, F., Labbé-Jullié, C., Kitabgi, P., Soubrié, P., Le Fur, G., \& Maffrand, J. P. (1997). Biochemical and pharmacological activities of SR 142948A, a new potent neurotensin receptor antagonist. The Journal of Pharmacology and Experimental Therapeutics, 280(2), 802-812.

Hauss-Wegrzyniak, B., Lukovic, L., Bigaud, M., \& Stoeckel, M. E. (1998). Brain inflammatory response induced by intracerebroventricular infusion of lipopolysaccharide: An immunohistochemical study. Brain Research, 794(2), 211-224. https://doi.org/10.1016/s0006-8993(98) 00227-3

Hauss-Wegrzyniak, B., Vraniak, P. D., \& Wenk, G. L. (2000). LPS-induced neuroinflammatory effects do not recover with time. Neuroreport, 11 (8), 1759-1763. https://doi.org/10.1097/00001756-20000605000032

Hernandez-Chan, N. G., Bannon, M. J., Orozco-Barrios, C. E., Escobedo, L., Zamudio, S., De la Cruz, F., Gongora-Alfaro, J. L., ArmendárizBorunda, J., Reyes-Corona, D., Espadas-Alvarez, A. J., FloresMartínez, Y. M., Ayala-Davila, J., Hernandez-Gutierrez, M. E., Pavón, L., García-Villegas, R., Nadella, R., \& Martinez-Fong, D. (2015). Neurotensin-polyplex-mediated brain-derived neurotrophic factor gene delivery into nigral dopamine neurons prevents nigrostriatal degeneration in a rat model of early Parkinson's disease. Journal of Biomedical Science, 22, 59. https://doi.org/10.1186/s12929-015-0166-7

Herschman, H. R. (1991). Primary response genes induced by growth factors and tumor promoters. Annual Review of Biochemistry, 60, 281-319. https://doi.org/10.1146/annurev.bi.60.070191.001433

Hol, E. M., \& Pekny, M. (2015). Glial fibrillary acidic protein (GFAP) and the astrocyte intermediate filament system in diseases of the central nervous system. Current Opinion in Cell Biology, 32, 121-130. https://doi. org/10.1016/j.ceb.2015.02.004

Houser, C. R. (2014). Do structural changes in GABA neurons give rise to the epileptic state? Advances in Experimental Medicine and Biology, 813, 151-160. https://doi.org/10.1007/978-94-017-8914-1_12

Hughes, P., Beilharz, E., Gluckman, P., \& Dragunow, M. (1993). Brainderived neurotrophic factor is induced as an immediate early gene following $\mathrm{N}$-methyl-d-aspartate receptor activation. Neuroscience, 57(2), 319-328. https://doi.org/10.1016/0306-4522(93)90065-N

Hwang, J.-I., Kim, D.-K., Kwon, H. B., Vaudry, H., \& Seong, J. Y. (2009). Phylogenetic history, pharmacological features, and signal transduction of neurotensin receptors in vertebrates. Annals of the New York Academy of Sciences, 1163, 169-178. https://doi.org/10.1111/j.17496632.2008.03636.x

Ivanov, A., Esclapez, M., Pellegrino, C., Shirao, T., \& Ferhat, L. (2009). Drebrin a regulates dendritic spine plasticity and synaptic function in mature cultured hippocampal neurons. Journal of Cell Science, 122(Pt 4), 524-534. https://doi.org/10.1242/jcs.033464

Jurcovicova, J. (2014). Glucose transport in brain-Effect of inflammation. Endocrine Regulations, 48(1), 35-48. https://doi.org/10.4149/endo_ 2014_01_35

Knake, S., Hamer, H. M., \& Rosenow, F. (2009). Status epilepticus: A critical review. Epilepsy \& Behavior: E\&B, 15(1), 10-14. https://doi.org/10. 1016/j.yebeh.2009.02.027
Kokko, K. P., Hadden, M. K., Price, K. L., Orwig, K. S., See, R. E., \& Dix, T. A. (2005). In vivo behavioral effects of stable, receptor-selective neurotensin[8-13] analogues that cross the blood-brain barrier. Neuropharmacology, 48(3), 417-425. https://doi.org/10.1016/j.neuropharm.2004.10.008

Koon, H.-W., Kim, Y. S., Xu, H., Kumar, A., Zhao, D., Karagiannides, I., Dobner, P. R., \& Pothoulakis, C. (2009). Neurotensin induces IL-6 secretion in mouse preadipocytes and adipose tissues during 2,4,6,trinitrobenzensulphonic acid-induced colitis. Proceedings of the National Academy of Sciences, 106(21), 8766-8771. https://doi.org/ 10.1073/pnas.0903499106

Kreitel, K. D., Swisher, C. B., \& Behbehani, M. M. (2002). The effects of diphenhydramine and SR142948A on periaqueductal gray neurons and on the interactions between the medial preoptic nucleus and the periaqueductal gray. Neuroscience, 114(4), 935-943. https://doi.org/ 10.1016/s0306-4522(02)00360-3

Lange, S. C., Bak, L. K., Waagepetersen, H. S., Schousboe, A., \& Norenberg, M. D. (2012). Primary cultures of astrocytes: Their value in understanding astrocytes in health and disease. Neurochemical Research, 37(11), 2569-2588. https://doi.org/10.1007/s11064-0120868-0

Lau, L. F., \& Nathans, D. (1991). Genes induced by serum growth factors. In P. Cohen \& J. G. Foulkes (Eds.), The hormonal control of gene transcription (pp. 257-293). Elsevier.

Lee, H.-K., Zhang, L., Smith, M. D., White, H. S., \& Bulaj, G. (2009). Glycosylated neurotensin analogues exhibit sub-picomolar anticonvulsant potency in a pharmacoresistant model of epilepsy. ChemMedChem, 4 (3), 400-405. https://doi.org/10.1002/cmdc.200800421

Lee, T. S., Eid, T., Mane, S., Kim, J. H., Spencer, D. D., Ottersen, O. P., \& de Lanerolle, N. C. (2004). Aquaporin-4 is increased in the sclerotic hippocampus in human temporal lobe epilepsy. Acta Neuropathologica, 108 (6), 493-502. https://doi.org/10.1007/s00401-004-0910-7

Lépée-Lorgeoux, I., Betancur, C., Rostène, W., \& Pélaprat, D. (1999). Differential ontogenetic patterns of levocabastine-sensitive neurotensin NT2 receptors and of NT1 receptors in the rat brain revealed by in situ hybridization. Brain Research. Developmental Brain Research, 113, 115-131. https://doi.org/10.1016/s0165-3806(99)00009-7

Mahler, M., Ferhat, L., Ben-Ari, Y., \& Represa, A. (1997). Effects of tenascin-C in cultured hippocampal astrocytes: NCAM and fibronectin immunoreactivity changes. Glia, 20(3), 231-242. https://doi.org/10. 1002/(sici)1098-1136(199707)20:3<231::aid-glia7>3.0.co;2-a

Manning, C. E., Eagle, A. L., Kwiatkowski, C. C., Achargui, R., Woodworth, H., Potter, E., Ohnishi, Y., Leinninger, G. M., \& Robison, A. J. (2019). Hippocampal subgranular zone FosB expression is critical for neurogenesis and learning. Neuroscience, 406, 225-233. https://doi.org/10.1016/j.neuroscience.2019.03.022

Martin, S., Vincent, J.-P., \& Mazella, J. (2002). Recycling ability of the mouse and the human neurotensin type 2 receptors depends on a single tyrosine residue. Journal of Cell Science, 115(Pt 1), 165-173.

Martin, S., Vincent, J.-P., \& Mazella, J. (2003). Involvement of the neurotensin receptor-3 in the neurotensin-induced migration of human microglia. The Journal of Neuroscience: The Official Journal of the Society for Neuroscience, 23(4), 1198-1205. https://doi.org/10.1523/ jneurosci.23-04-01198.2003

Martínez-González, J., \& Badimon, L. (2005). The NR4A subfamily of nuclear receptors: New early genes regulated by growth factors in vascular cells. Cardiovascular Research, 65(3), 609-618. https://doi.org/ 10.1016/j.cardiores.2004.10.002

Maxwell, M. A., \& Muscat, G. E. O. (2006). The NR4A subgroup: Immediate early response genes with pleiotropic physiological roles. Nuclear Receptor Signaling, 4, e002. https://doi.org/10.1621/nrs.04002

Mazella, J. (2001). Sortilin/neurotensin receptor-3: A new tool to investigate neurotensin signaling and cellular trafficking? Cellular Signalling, 13(1), 1-6. https://doi.org/10.1016/s0898-6568(00)00130-3

Mazella, J., Botto, J. M., Guillemare, E., Coppola, T., Sarret, P., \& Vincent, J. P. (1996). Structure, functional expression, and cerebral 
localization of the levocabastine-sensitive neurotensin/neuromedin $\mathrm{N}$ receptor from mouse brain. The Journal of Neuroscience: The Official Journal of the Society for Neuroscience, 16(18), 5613-5620. https://doi. org/10.1523/JNEUROSCI.16-18-05613.1996

Mazella, J., Zsürger, N., Navarro, V., Chabry, J., Kaghad, M., Caput, D. Ferrara, P., Vita, N., Gully, D., Maffrand, J. P., \& Vincent, J. P. (1998). The 100-kDa neurotensin receptor is gp95/sortilin, a non-G-proteincoupled receptor. The Journal of Biological Chemistry, 273(41), 2627326276. https://doi.org/10.1074/jbc.273.41.26273

Mazella, J., Pétrault, O., Lucas, G., Deval, E., Béraud-Dufour, S., Gandin, C., El-Yacoubi, M., Widmann, C., Guyon, A., Chevet, E., Taouji, S., Conductier, G., Corinus, A., Coppola, T., Gobbi, G., Nahon, J.-L., Heurteaux, C., \& Borsotto, M. (2010). Spadin, a Sortilin-derived peptide, targeting rodent TREK-1 channels: A new concept in the antidepressant drug design. PLoS Biology, 8(4), e1000355. https://doi.org/ 10.1371/journal.pbio.1000355

McMahon, S. B., \& Monroe, J. G. (1996). The role of early growth response gene 1 (egr-1) in regulation of the immune response. Journal of Leukocyte Biology, 60(2), 159-166. https://doi.org/10.1002/jlb.60.2.159

Mehendale, H. M., \& Apte, U. (2009). Hepatic defenses against toxicity: Liver regeneration and tissue repair. In A. Robert (Ed.), Comprehensive toxicology. Elsevier.

Mello, L. E., Cavalheiro, E. A., Tan, A. M., Kupfer, W. R., Pretorius, J. K., Babb, T. L., \& Finch, D. M. (1993). Circuit mechanisms of seizures in the pilocarpine model of chronic epilepsy: Cell loss and mossy fiber sprouting. Epilepsia, 34(6), 985-995. https://doi.org/10.1111/j.15281157.1993.tb02123.x

Mouri, G., Jimenez-Mateos, E., Engel, T., Dunleavy, M., Hatazaki, S., Paucard, A., Matsushima, S., Taki, W., \& Henshall, D. C. (2008). Unilateral hippocampal CA3-predominant damage and short latency epileptogenesis after intra-amygdala microinjection of kainic acid in mice. Brain Research, 1213, 140-151. https://doi.org/10.1016/j.brainres. 2008.03.061

Navarro, V., Martin, S., \& Mazella, J. (2006). Internalization-dependent regulation of HT29 cell proliferation by neurotensin. Peptides, 27(10), 2502-2507. https://doi.org/10.1016/j.peptides.2006.04.028

Nemeroff, C. B., Levant, B., Myers, B., \& Bissette, G. (1992). Neurotensin, antipsychotic drugs, and schizophrenia. Basic and clinical studies. Annals of the New York Academy of Sciences, 668, 146-156. https:// doi.org/10.1111/j.1749-6632.1992.tb27346.x

Nouel, D., Sarret, P., Vincent, J. P., Mazella, J., \& Beaudet, A. (1999). Pharmacological, molecular and functional characterization of glial neurotensin receptors. Neuroscience, 94(4), 1189-1197. https://doi.org/10. 1016/s0306-4522(99)00354-1

Obenaus, A., Esclapez, M., \& Houser, C. (1993). Loss of glutamate decarboxylase mRNA-containing neurons in the rat dentate gyrus following pilocarpine-induced seizures. The Journal of Neuroscience, 13(10), 44704485. https://doi.org/10.1523/JNEUROSCl.13-10-04470.1993

Ohsawa, K., Imai, Y., Sasaki, Y., \& Kohsaka, S. (2004). Microglia/macrophage-specific protein lba1 binds to fimbrin and enhances its actin-bundling activity. Journal of Neurochemistry, 88(4), 844-856. https://doi.org/10.1046/j.1471-4159.2003.02213.x

Ouyang, Q., Gong, X., Xiao, H., Zhou, J., Xu, M., Dai, Y., Xu, L., Feng, H., Cui, H., \& Yi, L. (2015). Neurotensin promotes the progression of malignant glioma through NTSR1 and impacts the prognosis of glioma patients. Molecular Cancer, 14, 21. https://doi.org/10.1186/s12943015-0290-8

Palacios, J. M., Pazos, A., Dietl, M. M., Schlumpf, M., \& Lichtensteiger, W. (1988). The ontogeny of brain neurotensin receptors studied by autoradiography. Neuroscience, 25(1), 307-317. https://doi.org/10.1016/ 0306-4522(88)90028-0

Pang, Y., Cai, Z., \& Rhodes, P. G. (2001). Analysis of genes differentially expressed in astrocytes stimulated with lipopolysaccharide using cDNA arrays. Brain Research, 914(1-2), 15-22. https://doi.org/10. 1016/s0006-8993(01)02766-4
Papageorgiou, I. E., Gabriel, S., Fetani, A. F., Kann, O., \& Heinemann, U. (2011). Redistribution of astrocytic glutamine synthetase in the hippocampus of chronic epileptic rats. Glia, 59(11), 1706-1718. https://doi. org/10.1002/glia.21217

Patel, A. B., Tsilioni, I., Leeman, S. E., \& Theoharides, T. C. (2016). Neurotensin stimulates sortilin and mTOR in human microglia inhibitable by methoxyluteolin, a potential therapeutic target for autism. Proceedings of the National Academy of Sciences of the United States of America, 113(45), E7049-E7058. https://doi.org/10.1073/pnas.1604992113

Paxinos, G., \& Franklin, K. (2019). The mouse brain in stereotaxic coordinates (5th ed.). Academic Press, Inc.

Paxinos, G., \& Watson, C. (1998). The rat brain in stereotaxic coordinates (4th ed.). Academic Press, Inc.

Perron, A., Sharif, N., Gendron, L., Lavallée, M., Stroh, T., Mazella, J., \& Beaudet, A. (2006). Sustained neurotensin exposure promotes cell surface recruitment of NTS2 receptors. Biochemical and Biophysical Research Communications, 343(3), 799-808. https://doi.org/10.1016/ j.bbrc.2006.03.047

Richard, F., Barroso, S., Martinez, J., Labbé-Jullié, C., \& Kitabgi, P. (2001). Agonism, inverse agonism, and neutral antagonism at the constitutively active human neurotensin receptor 2. Molecular Pharmacology, 60(6), 1392-1398. https://doi.org/10.1124/mol.60.6.1392

Rosi, S., Vazdarjanova, A., Ramirez-Amaya, V., Worley, P. F., Barnes, C. A., \& Wenk, G. L. (2006). Memantine protects against LPSinduced neuroinflammation, restores behaviorally-induced gene expression and spatial learning in the rat. Neuroscience, 142(4), 13031315. https://doi.org/10.1016/j.neuroscience.2006.08.017

Saada, S., Marget, P., Fauchais, A.-L., Lise, M.-C., Chemin, G., Sindou, P., Martel, C., Delpy, L., Vidal, E., Jaccard, A., Troutaud, D., Lalloué, F., \& Jauberteau, M.-O. (2012). Differential expression of neurotensin and specific receptors, NTSR1 and NTSR2, in normal and malignant human B lymphocytes. Journal of Immunology (Baltimore, Md.: 1950), 189(11), 5293-5303. https://doi.org/10.4049/jimmunol.1102937

Sarret, P., Beaudet, A., Vincent, J. P., \& Mazella, J. (1998). Regional and cellular distribution of low affinity neurotensin receptor mRNA in adult and developing mouse brain. The Journal of Comparative Neurology, 394(3), 344-356. https://doi.org/10.1002/(SICI)1096-9861 (19980511)394:3\%3C344::AID-CNE6\%3E3.0.CO;2-1

Sarret, P., \& Beaudet, A. (2002). Chapter VI: Neurotensin receptors in the central nervous system. In R. Quirion, A. Björklund, \& T. Hökfelt (Eds.), Handbook of chemical Neuroanatomy (Vol. 20, pp. 323-400). Elsevier. https://doi.org/10.1016/S0924-8196(02)80008-2

Sarret, P., Gendron, L., Kilian, P., Nguyen, H. M. K., Gallo-Payet, N., Payet, M.-D., \& Beaudet, A. (2002). Pharmacology and functional properties of NTS2 neurotensin receptors in cerebellar granule cells. The Journal of Biological Chemistry, 277(39), 36233-36243. https:// doi.org/10.1074/jbc.M202586200

Sarret, P., Perron, A., Stroh, T., \& Beaudet, A. (2003). Immunohistochemical distribution of NTS2 neurotensin receptors in the rat central nervous system. The Journal of Comparative Neurology, 461(4), 520-538. https://doi.org/10.1002/cne.10718

Sbai, O., Khrestchatisky, M., Esclapez, M., \& Ferhat, L. (2012). Drebrin a expression is altered after pilocarpine-induced seizures: Time course of changes is consistent for a role in the integrity and stability of dendritic spines of hippocampal granule cells. Hippocampus, 22(3), 477-493. https://doi.org/10.1002/hipo.20914

Sbai, O., Ould-Yahoui, A., Ferhat, L., Gueye, Y., Bernard, A., Charrat, E., Mehanna, A., Risso, J.-J., Chauvin, J.-P., Fenouillet, E., Rivera, S., \& Khrestchatisky, M. (2010). Differential vesicular distribution and trafficking of MMP-2, MMP-9, and their inhibitors in astrocytes. Glia, 58 (3), 344-366. https://doi.org/10.1002/glia.20927

Sbai, O., Soussi, R., Bole, A., Khrestchatisky, M., Esclapez, M., \& Ferhat, L. (2021). The Actin binding protein $\alpha$-actinin-2 expression is associated with dendritic spine plasticity and migrating granule cells in the rat dentate gyrus following pilocarpine-induced seizures. Experimental 
Neurology, 335, 113512. https://doi.org/10.1016/j.expneurol.2020. 113512

Schaeffer, P., Laplace, M. C., Bernat, A., Prabonnaud, V., Gully, D., Lespy, L., \& Herbert, J. M. (1998). SR142948A is a potent antagonist of the cardiovascular effects of neurotensin. Journal of Cardiovascular Pharmacology, 31(4), 545-550. https://doi.org/10.1097/00005344199804000-00012

Schauwecker, P. E., \& Steward, O. (1997). Genetic determinants of susceptibility to excitotoxic cell death: Implications for gene targeting approaches. Proceedings of the National Academy of Sciences of the United States of America, 94(8), 4103-4108. https://doi.org/10.1073/ pnas.94.8.4103

Schmidt-Kastner, R., \& Ingvar, M. (1994). Loss of immunoreactivity for glial fibrillary acidic protein (GFAP) in astrocytes as a marker for profound tissue damage in substantia nigra and basal cortical areas after status epilepticus induced by pilocarpine in rat. Glia, 12(3), 165-172. https:// doi.org/10.1002/glia.440120302

Seifert, G., Carmignoto, G., \& Steinhäuser, C. (2010). Astrocyte dysfunction in epilepsy. Brain Research Reviews, 63, 212-221. https://doi.org/10. 1016/j.brainresrev.2009.10.004

Shapiro, L. A., Wang, L., \& Ribak, C. E. (2008). Rapid astrocyte and microglial activation following pilocarpine-induced seizures in rats. Epilepsia, 49, 33-41. https://doi.org/10.1111/j.1528-1167.2008. 01491.x

Sharma, A. K., Reams, R. Y., Jordan, W. H., Miller, M. A., Thacker, H. L., \& Snyder, P. W. (2007). Mesial temporal lobe epilepsy: Pathogenesis, induced rodent models and lesions. Toxicologic Pathology, 35(7), 984-999. https://doi.org/10.1080/01926230701748305

Sharma, R. P., Janicak, P. G., Bissette, G., \& Nemeroff, C. B. (1997). CSF neurotensin concentrations and antipsychotic treatment in schizophrenia and schizoaffective disorder. The American Journal of Psychiatry, 154(7), 1019-1021. https://doi.org/10.1176/ajp.154.7. 1019

Shults, N. V., Almansour, F. S., Rybka, V., Suzuki, D. I., \& Suzuki, Y. J. (2018). Ligand-mediated dephosphorylation signaling for MAP kinase. Cellular Signalling, 52, 147-154. https://doi.org/10.1016/j.cellsig. 2018.09.005

Soussi, R., Boulland, J.-L., Bassot, E., Bras, H., Coulon, P., Chaudhry, F. A., Storm-Mathisen, J., Ferhat, L., \& Esclapez, M. (2015). Reorganization of supramammillary-hippocampal pathways in the rat pilocarpine model of temporal lobe epilepsy: Evidence for axon terminal sprouting. Brain Structure \& Function, 220(4), 2449-2468. https://doi.org/10. 1007/s00429-014-0800-2

Sperk, G., Wieser, R., Widmann, R., \& Singer, E. A. (1986). Kainic acid induced seizures: Changes in somatostatin, substance $P$ and neurotensin. Neuroscience, 17(4), 1117-1126. https://doi.org/10.1016/ 0306-4522(86)90081-3

St-Gelais, F., Jomphe, C., \& Trudeau, L.-E. (2006). The role of neurotensin in central nervous system pathophysiology: What is the evidence? Journal of Psychiatry \& Neuroscience: JPN, 31(4), 229-245.

Streit, W. J. (2010). Microglial activation and neuroinflammation in Alzheimer's disease: A critical examination of recent history. Frontiers in Aging Neuroscience, 2, 22. https://doi.org/10.3389/ fnagi.2010.00022

Sun, L., \& Ye, R. D. (2012). Role of G protein-coupled receptors in inflammation. Acta Pharmacologica Sinica, 33(3), 342-350. https://doi.org/ 10.1038/aps.2011.200

Tabarean, I. (2020). Neurotensin induces hypothermia by activating both neuronal neurotensin receptor 1 and astrocytic neurotensin receptor 2 in the median preoptic nucleus. Neuropharmacology, 2020, 108069. https://doi.org/10.1016/j.neuropharm.2020.108069

Tanaka, K., Masu, M., \& Nakanishi, S. (1990). Structure and functional expression of the cloned rat neurotensin receptor. Neuron, 4(6), 847-854. https://doi.org/10.1016/0896-6273(90)90137-5
Torup, L., Borsdal, J., \& Sager, T. (2003). Neuroprotective effect of the neurotensin analogue JMV-449 in a mouse model of permanent middle cerebral ischaemia. Neuroscience Letters, 351(3), 173-176. https:// doi.org/10.1016/j.neulet.2003.08.008

Uzunalli, G., Dieterly, A. M., Kemet, C. M., Weng, H.-Y., Soepriatna, A. H., Goergen, C. J., Shinde, A. B., Wendt, M. K., \& Lyle, L. T. (2019). Dynamic transition of the blood-brain barrier in the development of non-small cell lung cancer brain metastases. Oncotarget, 10(59), 6334-6348. https://doi.org/10.18632/oncotarget.27274

Vezzani, A., Balosso, S., \& Ravizza, T. (2008). The role of cytokines in the pathophysiology of epilepsy. Brain, Behavior, and Immunity, 22(6), 797-803. https://doi.org/10.1016/j.bbi.2008.03.009

Vezzani, A., French, J., Bartfai, T., \& Baram, T. Z. (2011). The role of inflammation in epilepsy. Nature Reviews. Neurology, 7(1), 31-40. https://doi. org/10.1038/nrneurol.2010.178

Vezzani, A., \& Granata, T. (2005). Brain inflammation in epilepsy: Experimental and clinical evidence. Epilepsia, 46(11), 1724-1743. https://doi. org/10.1111/j.1528-1167.2005.00298.x

Vincent, J. P. (1995). Neurotensin receptors: Binding properties, transduction pathways, and structure. Cellular and Molecular Neurobiology, 15 (5), 501-512. https://doi.org/10.1007/bf02071313

Vieira, M. J., Perosa, S. R., Argaãaraz, G. A., Silva, J. A., Jr., Cavalheiro, E. A., \& Graça Naffah-Mazzacoratti, M. D. (2014). Indomethacin can downregulate the levels of inflammatory mediators in the hippocampus of rats submitted to pilocarpine-induced status epilepticus. Clinics (São Paulo, Brazil), 69, 621-626. https://doi.org/10. 6061/clinics/2014(09)08

Vita, N., Oury-Donat, F., Chalon, P., Guillemot, M., Kaghad, M., Bachy, A., Thurneyssen, O., Garcia, S., Poinot-Chazel, C., Casellas, P., Keane, P., Le Fur, G., Maffrand, J. P., Soubrie, P., Caput, D., \& Ferrara, P. (1998). Neurotensin is an antagonist of the human neurotensin NT2 receptor expressed in Chinese hamster ovary cells. European Journal of Pharmacology, 360, 265-272. https://doi.org/10.1016/s0014-2999(98) 00678-5

Voutsinos-Porche, B., Koning, E., Kaplan, H., Ferrandon, A., Guenounou, M., Nehlig, A., \& Motte, J. (2004). Temporal patterns of the cerebral inflammatory response in the rat lithium-pilocarpine model of temporal lobe epilepsy. Neurobiology of Disease, 17, 385-402. https://doi.org/10.1016/j.nbd.2004.07.023

Walker, N., Lepee-Lorgeoux, I., Fournier, J., Betancur, C., Rostene, W., Ferrara, P., \& Caput, D. (1998). Tissue distribution and cellular localization of the levocabastine-sensitive neurotensin receptor mRNA in adult rat brain. Brain Research. Molecular Brain Research, 57(2), 193-200. https://doi.org/10.1016/s0169-328x(98)00074-6

Williams, F. G., Mullet, M. A., \& Beitz, A. J. (1995). Basal release of metenkephalin and neurotensin in the ventrolateral periaqueductal gray matter of the rat: A microdialysis study of antinociceptive circuits. Brain Research, 690(2), 207-216. https://doi.org/10.1016/0006-8993 (95)00554-4

Woodworth, H. L., Perez-Bonilla, P. A., Beekly, B. G., Lewis, T. J., \& Leinninger, G. M. (2018). Identification of Neurotensin receptor expressing cells in the ventral tegmental area across the lifespan. ENeuro, 5(1), 1-17. https://doi.org/10.1523/ENEURO.0191-17.2018

Xu, Z., Dziarski, R., Wang, Q., Swartz, K., Sakamoto, K. M., \& Gupta, D. (2001). Bacterial peptidoglycan-induced tnf- $\alpha$ transcription is mediated through the transcription factors Egr-1, Elk-1, and NF-kB. The Journal of Immunology, 167(12), 6975-6982. https://doi.org/10.4049/ jimmunol.167.12.6975

Yamaji, Y., Moe, O. W., Miller, R. T., \& Alpern, R. J. (1994). Acid activation of immediate early genes in renal epithelial cells. The Journal of Clinical Investigation, 94(3), 1297-1303. https://doi.org/10.1172/JCI117448

Yamauchi, R., Wada, E., Kamichi, S., Yamada, D., Maeno, H., Delawary, M., Nakazawa, T., Yamamoto, T., \& Wada, K. (2007). Neurotensin type 2 receptor is involved in fear memory in mice. Journal of Neurochemistry, 102(5), 1669-1676. https://doi.org/10.1111/j.1471-4159.2007.04805.x 
Yao, J., Mackman, N., Edgington, T. S., \& Fan, S. T. (1997). Lipopolysaccharide induction of the tumor necrosis factor-alpha promoter in human monocytic cells. Regulation by Egr-1, c-Jun, and NF-kappaB transcription factors. The Journal of Biological Chemistry, 272(28), 1779517801. https://doi.org/10.1074/jbc.272.28.17795

Zamanian, J. L., Xu, L., Foo, L. C., Nouri, N., Zhou, L., Giffard, R. G., \& Barres, B. A. (2012). Genomic analysis of reactive Astrogliosis. Journal of Neuroscience, 32(18), 6391-6410. https://doi.org/10.1523/ JNEUROSCI.6221-11.2012

Zhang, Y., Chen, K., Sloan, S. A., Bennett, M. L., Scholze, A. R., O'Keeffe, S., Phatnani, H. P., Guarnieri, P., Caneda, C., Ruderisch, N., Deng, S., Liddelow, S. A., Zhang, C., Daneman, R., Maniatis, T., Barres, B. A., \& Wu, J. Q. (2014). An RNA-sequencing transcriptome and splicing database of glia, neurons, and vascular cells of the cerebral cortex. The Journal of Neuroscience: The Official Journal of the Society for Neuroscience, 34(36), 11929-11947. https://doi.org/10.1523/JNEUROSCI.1860-14.2014

Zhao, D., Kuhnt-Moore, S., Zeng, H., Wu, J. S., Moyer, M. P., \& Pothoulakis, C. (2003). Neurotensin stimulates IL-8 expression in human colonic epithelial cells through rho GTPase-mediated NF-kappa B pathways. American Journal of Physiology. Cell Physiology, 284(6), C1397-C1404. https://doi.org/10.1152/ajpcell.00328.2002
Zhao, Y., \& Bruemmer, D. (2010). NR4A orphan nuclear receptors: Transcriptional regulators of gene expression in metabolism and vascular biology. Arteriosclerosis, Thrombosis, and Vascular Biology, 30(8), 1535-1541. https://doi.org/10.1161/ATVBAHA.109.191163

\section{SUPPORTING INFORMATION}

Additional supporting information may be found online in the Supporting Information section at the end of this article.

How to cite this article: Kyriatzis, G., Bernard, A., Bôle, A., Pflieger, G., Chalas, P., Masse, M., Lécorché, P., Jacquot, G., Ferhat, L., \& Khrestchatisky, M. (2021). Neurotensin receptor 2 is induced in astrocytes and brain endothelial cells in relation to neuroinflammation following pilocarpine-induced seizures in rats. Glia, 1-26. https://doi.org/10.1002/glia.24062 